\title{
Impact of soil physico-chemical properties on distribution of earthworm populations across different land use patterns in southern India
}

\author{
Anisetti Siva Sankar ${ }^{*}(1)$ and Aliva Patnaik
}

\begin{abstract}
Background: The distribution of earthworms is usually diverse and their population fluctuates in relation to the different physico-chemical properties and land use patterns of the soil of southern parts of India. This particular study examined distribution and relative abundance of earthworms under different land use patterns and their influence on the physico-chemical properties of the soil. We measured the species composition of earthworm communities across the three different land use ecosystems and effect of abiotic factors on them from various ecological regions of southern India (southern Odisha).
\end{abstract}

Methods: The linear relationship between different physico-chemical parameters of soil across three land use types and earthworm density is obtained by Pearson correlation analysis in the months of June to September. The association of physico-chemical parameters of different habitats with earthworm populations is analyzed using two-way ANOVA. Principal component analysis is (PCA) used to characterize the effect of different soil properties on the distribution of earthworm populations across three different habitats.

Results: A total of ten species of earthworms belonging to five families were identified. Four species of earthworms are identified, i.e., Pontodrilus bermudensis, Parionyx excavates, Pheretima alexandri, Lampito mauritii, most abundantly in forest lands, while the other six species are mostly found in agriculture and grass land. The earthworm density is significantly correlated $(P<0.01)$ with the availability of organic $O C$, total nitrogen, phosphorus, and water holding capacity across the three habitats, the forest land in particular. Both ANOVA and PCA results revealed a significant impact of habitat conditions on the soil physico-chemical properties as well as earthworm density.

Conclusions: This particular study has provided new information regarding the influence of different earthworm population on abiotic factors of soil across three land use patterns. It is also noticed that the distribution of earthworm was higher in forest lands and followed by grasslands having high organic manure rather than agricultural land.

Keywords: Landuse patterns, Earthworms, Habitat preferences, Soil abiotic factors

\footnotetext{
* Correspondence: sivasankar.anisetti@gmail.com

Ecology Division, School of Life sciences, Sambalpur University, Jyoti Vihar, Odisha 768019, India
} 


\section{Background}

Earthworms constitute the largest biological component of the soil among all animal biomass in soil and are commonly referred as ecosystem engineers (Blouin et al., 2013). Earthworms are considered to be the most important soil animals in many Indian subcontinental habitats. This consideration is based on their high density as well as their severe contribution to ecological and agronomical important aspects. Earthworms are one of the principal components of the invertebrate community in most soils, both in terms of their contribution to gross belowground biomass and their effects on soil biogeochemical cycles (Bohlen, Parmelee, McCartney, \& Edwards, 1997; James, 1991; Lee, 1985).

The soil physico-chemical characteristics like $\mathrm{pH}$, organic matter, nitrogen $(\mathrm{N})$, phosphorus $(\mathrm{P})$, etc. are influenced by earthworms due their participation in the association of the soil particles, as well as in organic matter transfer. The earthworms speed up $\mathrm{N}$ mineralization from organic matter, which sometimes depends on the specific species and their interaction with soil characteristics, organic matter geographical position. (Butenschoen, Ji, Schaeffer, \& Scheu, 2009). Hence, it is necessary to identify taxonomically those species which can survive tropical agroecosystems and significantly influence soil processes through intense activity toward a productive and sustainable soil ecosystem across various habitats (Lavelle, 1988).

There are many research works carried out across the globe which investigate the relationship between the activity of earthworms, the soil properties and environmental factors and have reported the increasing importance of earthworms. Various ecological studies have reported the close relationship between the availability of different earthworm species and various land use patterns (Nunes, Pasini, Benito, \& Brown, 2006; Tao et al., 2013). The distribution of earthworms is usually diverse and their density fluctuates in connection with the abiotic factors and land use patterns of the soil as well. The distribution of earthworm is usually heterogeneous (Guild, 1952; Satchell, 1955; Svendsen, 1957) and their numbers fluctuate in change in the abiotic factors of soil (Evans \& Guild, 1947). Environmental factors like temperature, pH, soil texture, and water content of soil also affect the distribution of earthworms. Bhadauria and Ramakrishnan (1989) reported that biotic and abiotic factors in particular soil properties, surface vegetation type, surface litter inputs, local/regional climate, human interference, and dynamic land management influences the regional earthworm biodiversity and species dispersal pattern. The diverse soil habitats have significant influence on factors affecting the complete earthworm distribution (Rajkhowa, Bhattacharyya, Sarma, \& Mahanta, 2014). Change in land use patterns (habitats) has direct consequences on the composition and population distribution of earthworm communities in various agro-climatic zones (Behera, Dash, \& Senapati, 1999; Bhadauria, Ramakrishnan, \& Srivastava, 2000; Blanchart \& Julka, 1997; Lalthanzara, Ramanujam, \& Jha, 2011). The association among biotic and abiotic factors, earthworm activities, climate change, and land use management practices are diverse and interrelated.

Indian earthworm fauna is composed of native species, which constitute about $89 \%$ of total earthworm diversity in the country (Julka \& Paliwal, 2005). The distribution of earthworm's population is affected by various land use system, soil water content, soil organic matter, rainfall pattern, etc. Many workers studied the habitat preference of various earthworm species (Bennour \& Nair, 1997; Singh, 1997; Singh, Singh, \& Vig, 2016). The presence or absence of a species particularly in a habitat and its non-appearance at some other habitats indicates the species-specific distribution of earthworms in different pedoecosystems (Tripathi \& Bhardwaj, 2004). Species vary in their ability to digest organic residues and assimilation of nutrients (Lattaud, Locati, Mora, \& Rouland, 1998).

Agricultural activities such as irrigation, tillage, lime application, pesticide use, drainage, and crop rotation can have influence on earthworm biomass and activity (Edwards \& Bohlen, 1996). Use of chemical substances such as solid materials and organic fertilizers obtained from plants and animal origins described to increase the populations of earthworm (Leroy, Schmidt, Van den Bossche, Reheul, \& Moens, 2008; Leroy, Van den Bossche, De Neve, Reheul, \& Moens, 2007; Reinecke, Albertus, Reinecke, \& Larink, 2008). In agriculture, performance of various activities by soil organisms like control of local microclimate, recycling of nutrients, and detoxification of chemicals regulate the density of unwanted soil fauna. The increase of earthworm populations in different forest soils has been limitedly explored. The impact of local anthropogenic activities, forest and soil physico-chemical properties on earthworm abundance with community composition is also an important consideration for future forest ecosystem. The resultant effect of forest ecosystem/cover is that it improves the water stable aggregates of the soil, more particularly in degraded lands which makes the earthworms living in suitable atmosphere. The incorporation of vegetation such as green manure in forest improves the physical and chemical properties of soil (Sharma \& Yogender, 2004). 
More research works are therefore needed to explore the unique soil earthworm habitats from southern parts of Odisha, India since this region represents an emerging area for the studies of physiological limits of invertebrate groups of soil macro faunal and their mechanisms of action toward sustainable agricultural improvement and for human welfare. To explore and characterize unexplored earthworm fauna is essential to study the diverse soil habitats such as soil texture of various habitats, agricultural soil, forest areas, grass land soil, etc., which would bring out some new valuable findings about the soil earthworm diversity and their distribution patterns across various habitats. There is also a need of distribution pattern of earthworms, as well as the factors affecting their distribution and modification of soil health by them. This paper addresses the present state of knowledge on earthworms' impacts on different soil structure and soil physico-chemical properties such as organic carbon $(\mathrm{OC}), \mathrm{pH}, \mathrm{N}$, water holding capacity (WHC), P, and cation exchange capacity (CEC) with special emphasis on the effects of land use practices at different habitats. The present research work is the first to report about the effect of specific abiotic components of soil on the distribution and density of earthworm species from various habitats of agro-climatic zones of Odisha, India. We have studied those factors which have influenced earthworm species diversity and community structure in agricultural fields, forest lands, as well as grass lands.

The aim of the present study is to determine the basis of distribution and relative abundance of variety of earthworm populations under different land use patterns and its relation with the physico-chemical properties of the soil. Here, we report the results of our study in which we measured the density and species composition of earthworm communities across three different land use ecosystems from various ecological regions of southern parts of Odisha, India.

\section{Methods}

\section{Study site and sampling}

The North Eastern Ghat is situated throughout the southern parts of state Odisha which consist of three different agro-climatic zones (zone no. 5, 6, 7). These zones include four districts, namely Rayagada, Ganjam, Koraput, and Gajapati. A global positioning system (GPS) was used to mark the latitude and longitude of each site. We have chosen three different habitats such as agriculture land, forest land, and grass and from each district (Table 1). Earthworms and adjacent soil samples were collected from the study sites by random sampling, particularly near the site of surface casting. Five random samples $(30 \mathrm{~cm} \times$ $30 \mathrm{~cm} \times 30 \mathrm{~cm}$ ) located at least $10 \mathrm{~m}$ apart were taken. The collected samples of earthworms with appropriate mass of soil were placed in polythene bags labeled with place name, date of collection, surrounding soil biota, etc. and brought to the lab for further study. The soil samples were transferred to an enameled tray, the earthworms were collected by the hand sorting and wet sieving method, morphologically identified, and placed in a $4 \%$ formalin solution. Adjacent soil samples are air-dried, ground, and passed through $0.2 \mathrm{~mm}$-mesh sieve for chemical analysis (Ghosh, Bajaj, Hasan, \& Singh, 1983).

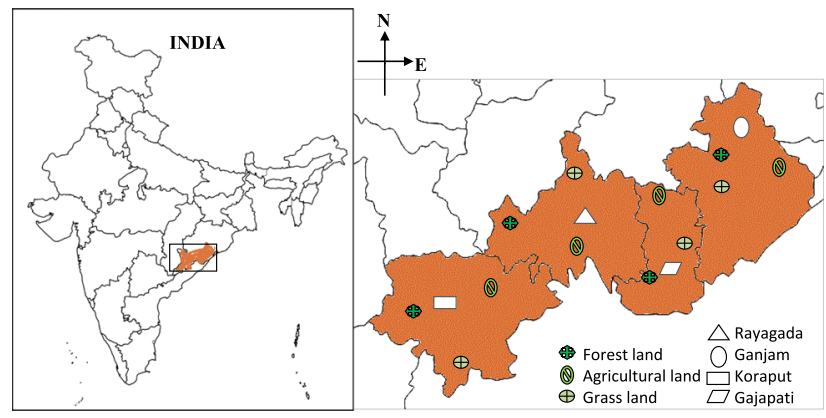

Experimental sites of different districts of Odisha, India.

\section{Physico-chemical parameters analysis}

Total nitrogen presumed equal to and measured using the total Kjeldahl method (Bremner, 1996), assuming limited mass of nitrite/nitrate because little amount of fertilizer is applied to the sampling locations. OC is measured using the Walkley-Black method (Nelson \& Sommers, 1996). The $\mathrm{pH}$ is determined in a media water suspension $(1: 1 \mathrm{w} / \mathrm{v})$ using a glass cathode microprocessor $\mathrm{pH}$ meter (Hanna Instruments $\mathrm{pH} 210$ ). pH-buffered $\mathrm{CEC}$ measurement is done at $\mathrm{pH}$ 7.0. Ammonium acetate procedure of Chapman (1965) followed for the estimation of CEC. P concentration of the soil sample is estimated by colorimetric method. Soil water content is estimated by keeping fresh soil samples in an oven drying at $105{ }^{\circ} \mathrm{C}$ until constant weight. WHC is measured by using sintered crucibles filled with oven dried and sieved through $2 \mathrm{~mm}$ mesh soil samples kept over a container filled with water and kept for $24 \mathrm{~h}$.

\section{Statistical analysis}

The linear relationship between different physico-chemical parameters of soil and earthworm density is obtained by Pearson correlation analysis. The association of physico-chemical parameters of various habitats with earthworm populations is analyzed using two-way ANOVA. All the experiments were done with $n=5$ repetitions from each sampling site. Principal component analysis (PCA) is used to characterize the effect of different soil properties on the distribution of earthworm populations across three different habitats. All the analyses are done with the help of SPSS 17 software program. 
Table 1 Description of study sites with latitude, longitude, and type of habitat

\begin{tabular}{|c|c|c|c|c|}
\hline \multirow[t]{2}{*}{ Study site } & \multirow[t]{2}{*}{ Site number } & \multirow{2}{*}{$\begin{array}{l}\text { Latitude } \\
\text { North }\end{array}$} & Longitude & \multirow[t]{2}{*}{ Habitat } \\
\hline & & & East & \\
\hline \multirow[t]{2}{*}{ Muninguda, Rayagada } & \multirow[t]{2}{*}{ I } & 19.62115 & 83.49875 & \multirow[t]{2}{*}{ Agriculture land } \\
\hline & & N $19^{\circ} 37^{\prime} 16.1414^{\prime \prime}$ & E $83^{\circ} 29^{\prime} 55.49^{\prime \prime}$ & \\
\hline \multirow[t]{2}{*}{ Ramanaguda range, Rayagada } & \multirow[t]{2}{*}{$\|$} & $19.21^{\circ} 67$ & 83.67326 & \multirow[t]{2}{*}{ Forest land } \\
\hline & & N $19^{\circ} 12^{\prime} 384231^{\prime \prime}$ & E $83^{\circ} 40^{\prime} 23.73^{\prime \prime}$ & \\
\hline \multirow[t]{2}{*}{ Royat colony, Rayagada } & \multirow[t]{2}{*}{ III } & 19.16813 & 83.40781 & \multirow[t]{2}{*}{ Grass land } \\
\hline & & N $19^{\circ} 10^{\prime} 527^{\prime \prime}$ & E $83^{\circ} 24^{\prime} 28.127^{\prime \prime}$ & \\
\hline \multirow[t]{2}{*}{ Bhanjanagar, Ganjam } & \multirow[t]{2}{*}{ IV } & 19.35919 & 84.97379 & \multirow[t]{2}{*}{ Agriculture land } \\
\hline & & N $19^{\circ} 21^{\prime} 33.07^{\prime \prime}$ & $\mathrm{E} 84^{\circ} 58^{\prime} 25640^{\prime \prime}$ & \\
\hline \multirow[t]{2}{*}{ Mujagada forest range, Ganjam } & \multirow[t]{2}{*}{ V } & 19.93273 & 84.58382 & \multirow[t]{2}{*}{ Forest land } \\
\hline & & N $19^{\circ} 55^{\prime} 57.8406^{\prime \prime}$ & E $84^{\circ} 35^{\prime} 1.759^{\prime \prime}$ & \\
\hline \multirow[t]{2}{*}{ Berhampur, Ganjam } & \multirow[t]{2}{*}{$\mathrm{Vl}$} & 20.42404 & 85.91959 & \multirow[t]{2}{*}{ Grass land } \\
\hline & & N 20 $25^{\prime} 26.5436^{\prime \prime}$ & E $85^{\circ} 55^{\prime} 10.53768^{\prime \prime}$ & \\
\hline \multirow[t]{2}{*}{ Semiliguda, Koraput } & \multirow[t]{2}{*}{ VII } & 18.74615 & 82.79403 & \multirow[t]{2}{*}{ Agriculture land } \\
\hline & & N $18^{\circ} 44^{\prime} 46.1526^{\prime \prime}$ & E $82^{\circ} 47^{\prime} 38.50728^{\prime \prime}$ & \\
\hline \multirow[t]{2}{*}{ Damonjodi, Koraput } & \multirow[t]{2}{*}{ VIII } & 18.76462 & 82.87754 & \multirow[t]{2}{*}{ Forest land } \\
\hline & & N $18^{\circ} 45^{\prime} 52.63272^{\prime \prime}$ & E $82^{\circ} 52^{\prime} 39.13896^{\prime \prime}$ & \\
\hline \multirow[t]{2}{*}{ Jaypore, Koraput } & \multirow[t]{2}{*}{ IX } & 18.81 .49 & 82.71233 & \multirow[t]{2}{*}{ Grass land } \\
\hline & & N $18^{\circ} 48^{\prime} 48.5532^{\prime \prime}$ & E $82^{\circ} 42^{\prime} 44.39772^{\prime \prime}$ & \\
\hline \multirow[t]{2}{*}{ Gajapatinagaram, Gajapati } & \multirow[t]{2}{*}{$x$} & 19.06123 & 83.82743 & \multirow[t]{2}{*}{ Agriculture land } \\
\hline & & N $19^{\circ} 3^{\prime} 40.41216^{\prime \prime}$ & E $83^{\circ} 49^{\prime} 27.48036^{\prime \prime}$ & \\
\hline Devagiri, paralakhemundi & $X I$ & 18.78172 & 83.42675 & Forest land \\
\hline & & N $18^{\circ} 46^{\prime} 54.17832^{\prime \prime}$ & E $83^{\circ} 25^{\prime} 36.30648^{\prime \prime}$ & \\
\hline Paralakhemundi, Gajapati & $X \|$ & 18.77826 & 84.09368 & Grass land \\
\hline & & N $18^{\circ} 46^{\prime} 41.75256^{\prime \prime}$ & E $84^{\circ} 5^{\prime} 37.23756^{\prime \prime}$ & \\
\hline
\end{tabular}

\section{Results}

Morphological characteristics

Samples collected from different habitats of four districts are identified as Lampito mauritii, Perionyx excavates, Pontodrilus bermudensis, Perionyx gravely, Eudrilus eugeniae, Octochaetona surensis, Pontoscolex corethrurus, Octochaetona serrata, Pheretima alexandri, and Eisenia fetida based on key morphological features such as length, number of segments, position of clitellum, position of spermathacae, and position of male and female pores on the segments (Table 2). Species identification was carried out at Zoological survey of India Kolkata, India by following standard protocols by Julka and Senapati (1987). The Pheretima alexandri sampled from Gajapati district found longest $(162 \mathrm{~mm})$ species and Eisenia fetida collected from Ganjam district was smallest $(76 \mathrm{~mm})$ in body length. The Pheretima alexandri had more number of segments (136) compared with other species. Eisenia fetida collected from Ganjam district found to have fewer no. of segments (72). The position of clitellum is varied from species to species. Four species of earthworms were identified, i.e., Pontodrilus bermudensis, Perionyx excavates, Pheretima alexandri, Lampito mauritii, found most abundantly in forest lands, while the other six species are mostly found in agriculture and grass land (Table 3). The populations of Eudrilus eugeniae, Octochaetona serrata, and Octochaetona surensis were found abundantly in several agricultural lands. Eisenia fetida, Pontoscolex corethrurus, and Perionyx gravely species mostly found in the areas of grass lands. Some populations found at both the habitats of forest and grass land such as Lampito mauritti and Perionyx excavates (Table 7).

\section{Correlation between earthworms and soil physico- chemical properties across three habitats}

The presence of a species in a particular habitat and its absence in other habitats shows the species-specific distribution of earthworms. The distribution of earthworm enhances the biological diversity and soil environment. 
Table 2 Morphological characteristics of earthworm populations collected

\begin{tabular}{|c|c|c|c|c|c|}
\hline SI no & Name of the species & Body length(mm) & Clitellum position & Clitellum length (mm) & Average body weight (g) \\
\hline 1 & Eisenia fetida & $65-70$ & $13-20$ & $2.10-3.30$ & 0.5 \\
\hline 2 & Eudrilus eugeniae & $70-130$ & $13-20$ & $2.50-5.00$ & 0.7 \\
\hline 3 & Lampito mauritii & $120-160$ & $13-20$ & $4.20-6.00$ & 1.2 \\
\hline 4 & Octochaetona serrate & $100-140$ & $13-20$ & $2.70-4.60$ & 0.8 \\
\hline 5 & Octochaetona surensis & $65-80$ & $13-20$ & $2.10-3.20$ & 0.7 \\
\hline 6 & Perionyx excavates & $100-120$ & $13-20$ & $2.30-5.20$ & 0.6 \\
\hline 7 & Perionyx gravely & $110-120$ & $13-20$ & $2.40-5.50$ & 0.8 \\
\hline 8 & Pheretima alexandri & $120-150$ & $13-20$ & $3.50-5.70$ & 0.6 \\
\hline 9 & Pontodrilus bermudensis & $80-130$ & $13-20$ & $3.10-4.50$ & 1.1 \\
\hline 10 & Pontoscolex corethrurus & $90-130$ & $13-20$ & $2.40-4.80$ & 0.7 \\
\hline
\end{tabular}

There was a significant $(P<0.01)$ positive correlation between earthworm abundance and all the soil physico-chemical parameters also observed as a whole. There were a significant difference in earthworm abundance $(P \leq 0.01)$ between agriculture land, forest land, and grassland observed for the three soil types (Table 4). A significant correlation between earthworm density and adjacent soil physico-chemical properties is noticed (Fig. 1a-f) across the three habitats as a whole. The earthworm density is significantly correlated $(P<0.01)$ with the availability of $\mathrm{OC}, \mathrm{N}, \mathrm{P}$, and $\mathrm{WHC}$ across the three habitats, specifically in the forest land. The $\mathrm{pH}$ and CEC found negatively correlated across agriculture and grass land. OC, N, P, and WHC were observed highest in forest land then grass land and agricultural land (Figs. 2, 3, 4, 5, 6, and 7). There was no significant correlation observed between earthworm density and most of the soil properties in agricultural land (Table 5).

\section{Analysis of variance of earthworm population with respect} to soil physico-chemical parameters of different habitats

Based on the results of this study, the earthworm abundance and physico-chemical parameters differed significantly among all the habitats (Table 6). ANOVA revealed a significant impact of habitat types on the soil physico-chemical properties as well as earthworm density. As a whole the, OC, $\mathrm{N}$ concentration, along with WHC of all the three habitats were significantly $(P<0.05)$ associated with earthworm abundance. The earthworm population was significantly increased in the forest land if we compare with agriculture and grass land. The OC was found highest $\left(15.6 \pm 0.74,15.3 \pm 1.44\left(\mathrm{mg} \mathrm{g}^{-1}\right)\right)$ in the forest land of both Rayagada and Ganjam districts and was found lowest (10.1 $\pm 0.41 \mathrm{mg} \mathrm{g}^{-1}$ each) in agriculture lands of the same districts. $\mathrm{N}$ concentration was found highest $\left(1.34 \pm 0.054,1.28 \pm 0.13 \mathrm{mg} \mathrm{g}^{-1}\right)$ in forest lands of Rayagada and Ganjam districts. WHC was highest

Table 3 Physico-chemical parameters of soil habitats of southern parts of India

\begin{tabular}{|c|c|c|c|c|c|c|c|c|}
\hline District & Habitat & EP & $C\left(\mathrm{mg} \mathrm{g}^{-1}\right)$ & $N\left(\mathrm{mg} \mathrm{g}^{-1}\right)$ & $\mathrm{pH}$ & Phosphorus (mg/kg) & WHC (\%) & CEC (meq/100 g) \\
\hline \multirow[t]{3}{*}{ Rayagada } & $\mathrm{AL}(\mathrm{I})$ & $18.4 \pm 2.47$ & $10.1 \pm 0.54$ & $1.04 \pm 0.11$ & $6.6 \pm 0.35$ & $25.44 \pm 4.69$ & $24.16 \pm 0.91$ & $6.2 \pm 0.83$ \\
\hline & $\mathrm{FL}(\mathrm{II})$ & $30.2 \pm 2.44$ & $15.6 \pm 0.74$ & $1.34 \pm 0.054$ & $6.72 \pm 0.19$ & $30.46 \pm 3.53$ & $28.70 \pm 2.03$ & $16.2 \pm 1.48$ \\
\hline & $\mathrm{GL}(I I I)$ & $23 \pm 1.04$ & $13.5 \pm 0.79$ & $1.16 \pm 0.054$ & $6.68 \pm 0.23$ & $28.15 \pm 3.57$ & $24.53 \pm 2.24$ & $16 \pm 1$ \\
\hline \multirow[t]{3}{*}{ Ganjam } & $\mathrm{AL}(\mathrm{IV})$ & $16 \pm 1.96$ & $10.1 \pm 0.41$ & $0.86 \pm 0.054$ & $6.52 \pm 0.28$ & $20.84 \pm 2.30$ & $23.92 \pm 0.52$ & $7.6 \pm 1.14$ \\
\hline & $\mathrm{FL}(\mathrm{V})$ & $28 \pm 0.73$ & $15.3 \pm 1.44$ & $1.28 \pm 0.13$ & $7.02 \pm 0.36$ & $30.32 \pm 3.46$ & $29.50 \pm 0.90$ & $23 \pm 2.23$ \\
\hline & $\mathrm{GL}(\mathrm{Vl})$ & $17.2 \pm 2.32$ & $11.9 \pm 0.96$ & $1.04 \pm 0.11$ & $6.74 \pm 0.18$ & $23.72 \pm 2.46$ & $25.03 \pm 0.78$ & $15.6 \pm 2.70$ \\
\hline \multirow[t]{3}{*}{ Koraput } & AL (VII) & $12.6 \pm 2.32$ & $11.5 \pm 0.79$ & $1.02 \pm 0.08$ & $6.48 \pm 0.44$ & $20.42 \pm 4.89$ & $25.86 \pm 1.77$ & $8.4 \pm 1.14$ \\
\hline & $\mathrm{FL}(\mathrm{VIII})$ & $21 \pm 2.24$ & $14.5 \pm 1.06$ & $1.22 \pm 0.083$ & $6.74 \pm 0.23$ & $28.64 \pm 3.18$ & $28.83 \pm 1.02$ & $22.2 \pm 1.48$ \\
\hline & GL (IX) & $15.8 \pm 1.84$ & $12.6 \pm 0.96$ & $1.08 \pm 0.083$ & $6.7 \pm 0.25$ & $23.89 \pm 3.91$ & $25.51 \pm 1.18$ & $13.6 \pm 1.14$ \\
\hline \multirow[t]{3}{*}{ Gajapati } & $A L(X)$ & $11.2 \pm 1.19$ & $11.6 \pm 0.74$ & $1.02 \pm 0.13$ & $6.42 \pm 0.31$ & $22.57 \pm 3.94$ & $23.69 \pm 1.19$ & $8 \pm 1.58$ \\
\hline & $\mathrm{FL}(\mathrm{XI})$ & $16.6 \pm 2.03$ & $14.6 \pm 0.96$ & $1.2 \pm 0.07$ & $6.92 \pm 0.33$ & $29.55 \pm 2.40$ & $28.51 \pm 0.74$ & $22.4 \pm 1.81$ \\
\hline & $\mathrm{GL}(X \mathrm{XI})$ & $15 \pm 1.12$ & $12.6 \pm 0.41$ & $0.96 \pm 0.11$ & $6.78 \pm 0.19$ & $26.74 \pm 4.27$ & $24.30 \pm 1.12$ & $14.2 \pm 1.92$ \\
\hline
\end{tabular}

$E P$ earthworm population, $C$ organic carbon, $N$ total nitrogen, WHC water holding capacity, CEC cation exchange capacity, $A L$ agricultural land, $F L$ forest land, GL grass land 
Table 4 Correlation coefficient ( $r$ ) of earthworm density with soil carbon, total nitrogen, $\mathrm{pH}$, phosphorus, WHC, and CEC across three different habitats

\begin{tabular}{llll}
\hline Physico-chemical properties & Agriculture land & Forest land & Grass land \\
\hline Organic carbon & -.368 & $.234^{* *}$ & .170 \\
Total Nitrogen & .093 & $.409^{* *}$ & .160 \\
$\mathrm{pH}$ & -.266 & .086 & $.268^{*}$ \\
Phosphorus & $.150^{*}$ & .116 & .160 \\
WHC & -.169 & .028 & -.127 \\
CEC & -.119 & -.457 & .119 \\
\hline
\end{tabular}

** Correlation is significant at 0.01 level

* Correlation is significant at 0.05 level

(25.50\%) nearly in all the districts. The overall $\mathrm{pH}$ found to be significantly $(P<0.05)$ basic in nature at forest lands and acidic in agriculture lands of all the districts. The $P$ values ranges from $20.42 \pm 4.89$ to $30.46 \pm 3.53 \%$. The differences between forest soils and grassland soils, and forest soils and agricultural soils were found to be statistically significant $(P<0.05)$, whereas the difference between agricultural and grassland soils was not significant.

\section{Principal component analysis}

Principal component analysis (PCA) is used on 6 physico-chemical parameters of soil for 15 sites from each of the habitat (agriculture land, forest land, and grass land) to identify the most important factors affecting earthworm distribution. Eigenvalues greater than 1 are considered as standard for extraction of the principal components analysis. PCA resulted in five principal components viz. $\mathrm{PC} 1, \mathrm{PC} 2, \mathrm{PC} 3$, and $\mathrm{PC} 4$ contributing variances of 28.058, 25.698, 23.471, and 21.446 respectively. The different factors, respective eigenvalues, total variance (\%), and cumulative variance (\%) for the each component are given in Table 5. The scree plot (Figs. 8, 9, and 10) for four principal components clarifies the method of extraction of different components. Variance in $\mathrm{PC} 1$ is due to $\mathrm{OC}, \mathrm{N}, \mathrm{WHC}$, and CEC; in PC2, it is due to OC, N, WHC, and $\mathrm{P}$; in $\mathrm{PC} 3$, it is due to $\mathrm{OC}, \mathrm{N}$, and $\mathrm{P}$; and in $\mathrm{PC} 4$, it is due to $\mathrm{OC}, \mathrm{N}, \mathrm{WHC}$, and CEC.

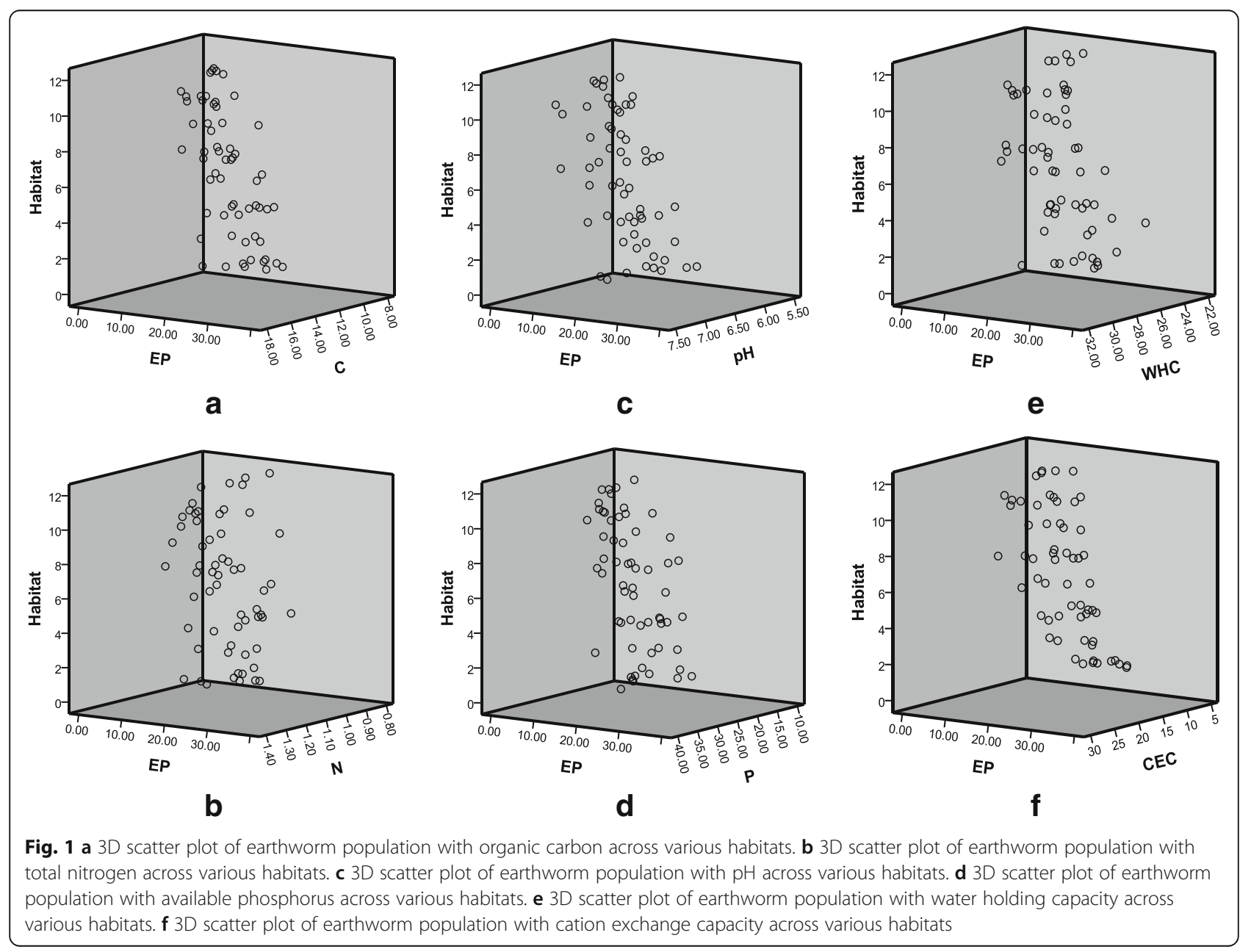




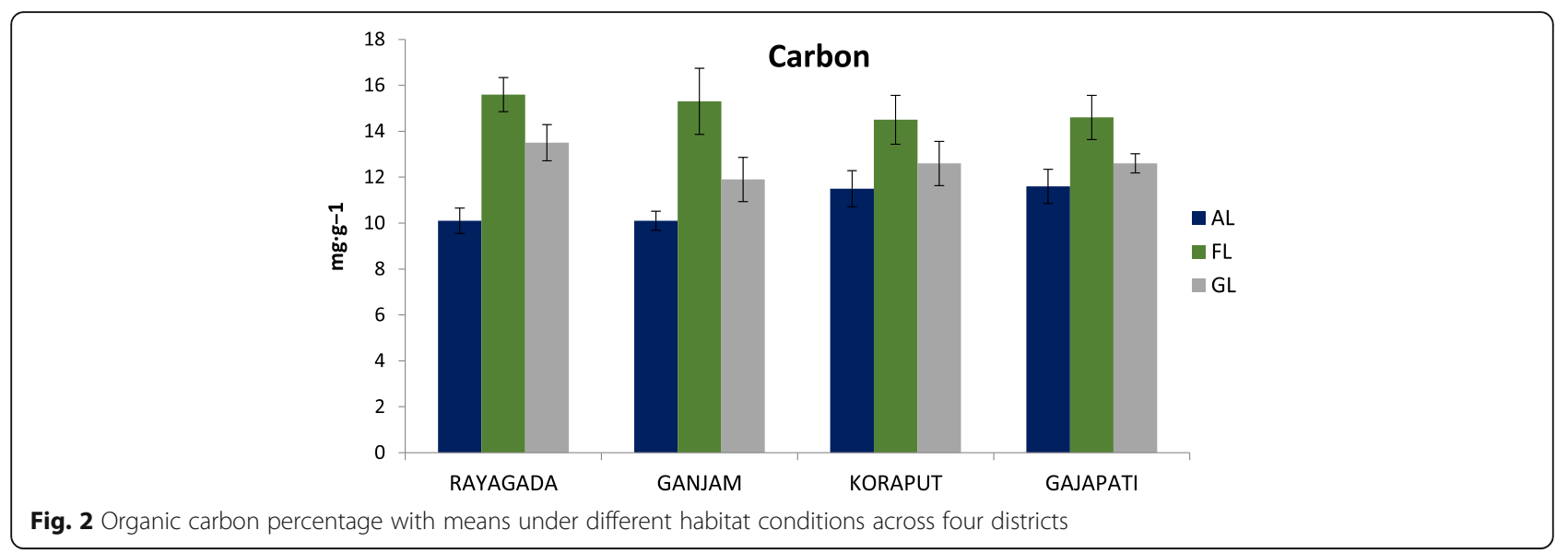

\section{Discussion}

In many regions, the type of vegetation is the major biotic factor which directly influences the distribution and diversity of earthworms in the soil (Ramanujam, Roy, \& Jha, 2000). The earthworms population vary in size ranging from only few individuals (sometimes totally absent) to more than $1000 / \mathrm{m}^{2}$, which depends on the physico-chemical characteristic of the soil and the climatic (Kale \& Karmegam, 2010; Lee, 1985). The change in soil texture and characteristic can influence the population of earthworm. Thus, they can serve as best indicators of several changes/factors associated with soil. Management of soil conditions can thus influence soil properties by affecting aggregation directly or indirectly to earthworm abundance and their subsequent contribution to change in soil structure.

The population of earthworm species and relative significance of different ecological categories are affected by the type of vegetation, abiotic factors, and the soil characteristics (Lavelle \& Spain, 2001). Soil aggregate stability was primarily specific in relation to different land use patterns and subsequently affected by earthworm activity within their ecosystem. However, many studies have examined both anthropogenic and environmental controls on earthworm populations in agricultural systems, forest land, and grass land. Soil degradation is also associated directly with the decreases in abundances and diversity of earthworm population and other invertebrate communities (Lavelle, 1997; Lee \& Foster, 1991). Tripathi and Bhardwaj (2004) reported high species richness in agricultural lands but in our study, species richness was very low $(11.2 \pm 1.19)$ in cultivated lands. The difference may be due to type of soil and agricultural practices followed at different regions. The reorganization of soil structure with the movement of earthworm through the soil and also during gut transit influences the physico-chemical properties of soil. The distribution of earthworm is usually heterogeneous (Guild, 1952; Satchell, 1955; Svendsen, 1957) and their population densities fluctuate in relation to the abiotic factors of the soil (Evans \& Guild, 1947). Bhadauria and Ramakrishnan (1989) reported different biotic and abiotic forces such as soil properties, surface litter inputs, local or regional climate, dynamic land management

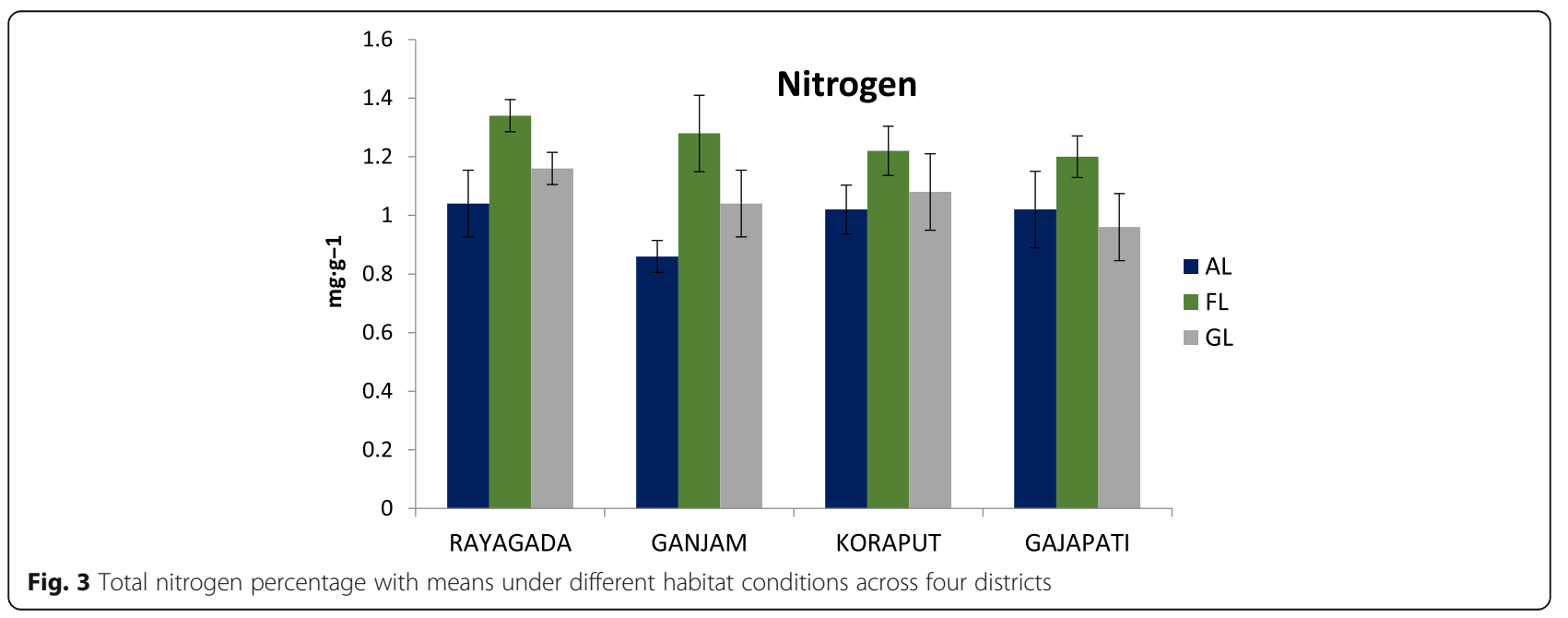




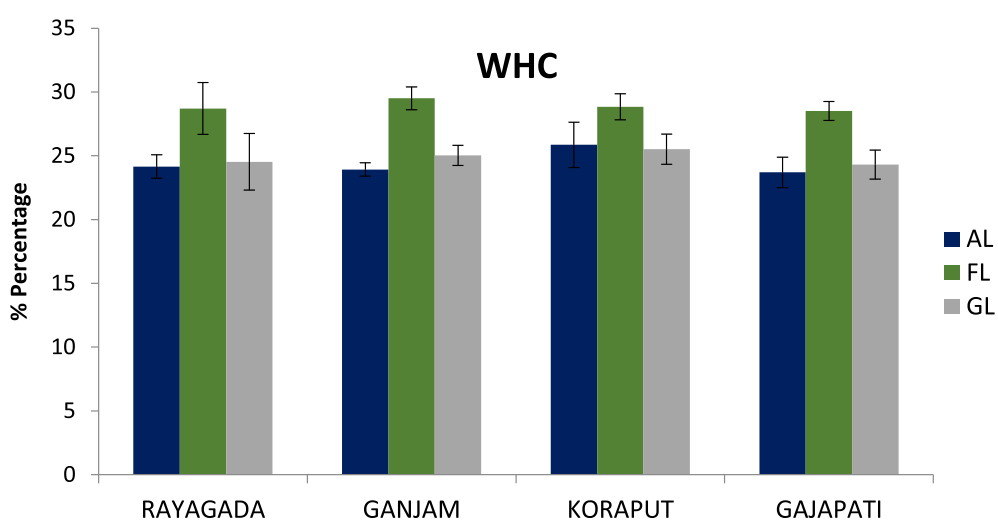

Fig. 4 Water holding capacity of soil with means under different habitat conditions across four districts

history, surface vegetation type, and human pressure at an extent are some of the major causes which effects the regional earthworm biodiversity and species dispersal pattern. Diverse soil habitats are the most direct influencing factors that are affecting the overall earthworm distribution in a particular ecological zone (Rajkhowa et al., 2014). Changes in different land use patterns have also directly affected the composition and population structure of earthworm communities in different agro-climatic regions (Behera et al., 1999; Bhadauria et al., 2000; Blanchart \& Julka, 1997; Lalthanzara et al., 2011).

Ten different species belonging to five families of the class Oligochaeta were sampled from the various habitats of study locations. Of the ten earthworm species, four species were identified, i.e., Pontodrilus bermudensis, Parionyx excavates, Pheretima alexandri, and Lampito mauritii, most abundantly in forest lands, while the other six species were found in agriculture and grass land very often. The populations of Eudrilus eugeniae, Octochaetona serrata, and Octochaetona surensis were found abundantly in several agricultural lands. Eisenia fetida, Pontoscolex corethrurus, and Perionyx gravely species were mostly found in the areas of grass lands. However, some of the populations were found at both the habitats of forest and grass land such as Lampito mauritii and Parionyx excavates (Table 7). The highest mean abundance of adults found at forest sites followed by grassland and cultivated land. The differences between sites can be very high as indicated by the coefficient of variation for all habitat types. Changes in vegetation can affect the distribution and abundance of earthworms through changes in litter quality and also through soil properties dynamics (Muys \& Granval, 1997). The presence of species in a particular habitat and its absence in other shows the species-specific distribution of earthworms in respective soil ecosystems. Similar observations were mentioned in the earthworm species composition at different grasslands, cultivated and forest soils (Singh, 1997) Hackenberger and Hackenberger (2014) showed that endogeic species were dominant in all seasons while the anecic category was only represented by one species per location or was completely absent. Our results are consistent with the findings of Holland (2004), Singh et al. (2016), and Rajkhowa, Bhattacharyya, Sarma,

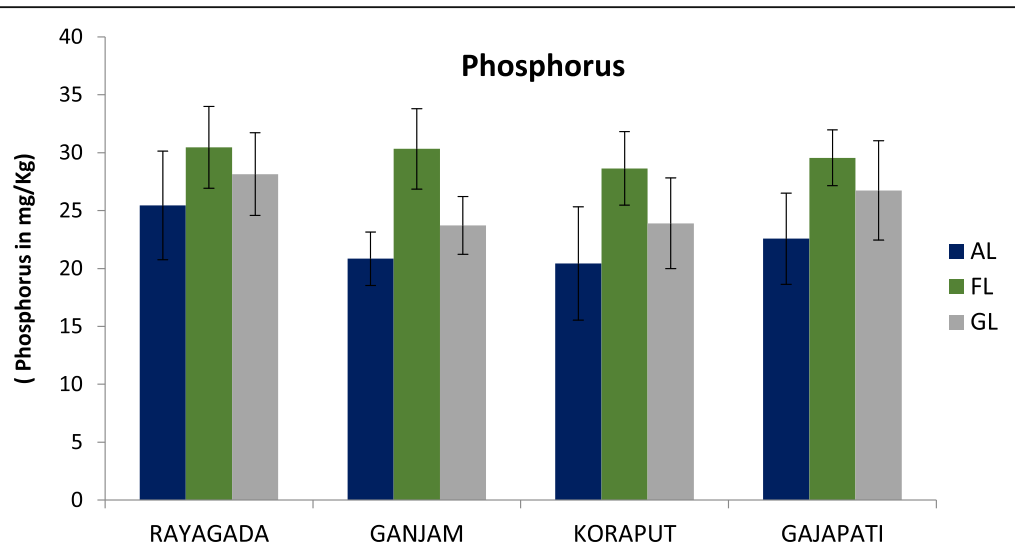

Fig. 5 Available phosphorus percentage with means under different habitat conditions across four districts 


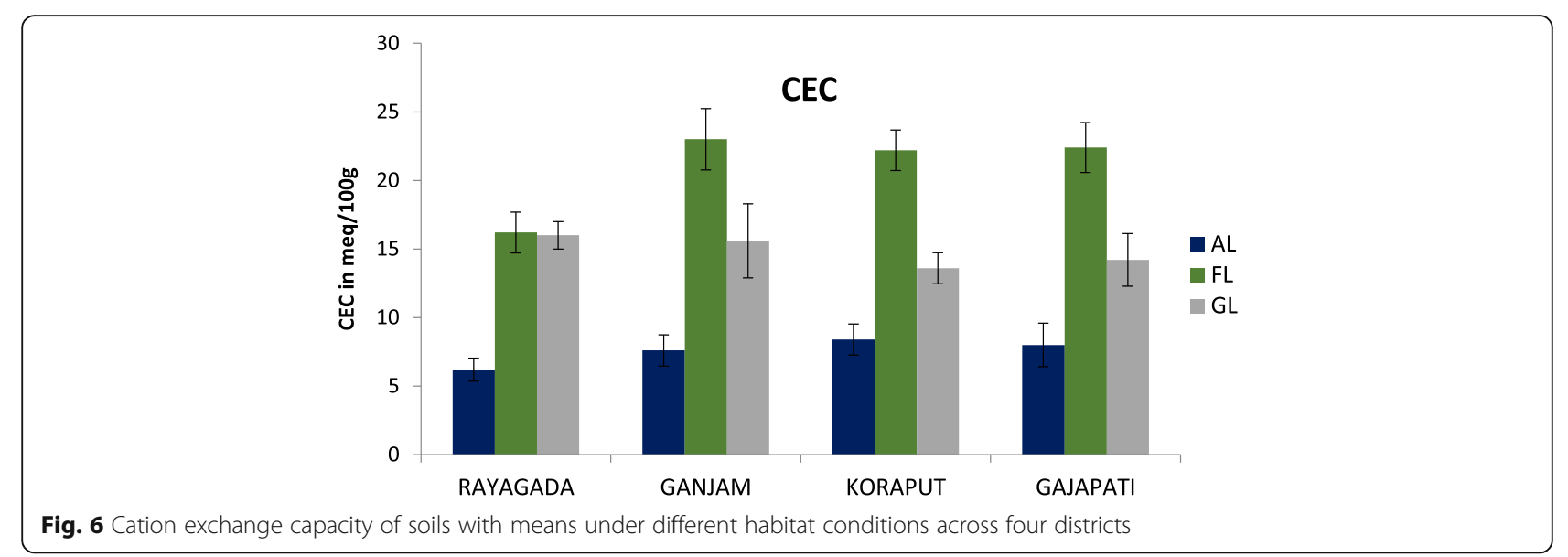

and Mahanta (2015) that presented the relationship between soil structure and earthworm diversity. Higher earthworm diversity recorded in forest soil and grassland due to usage of inorganic pesticides and insecticide very less amount.

These species represent two anecic, four endogeic, and four epigeic species. The overall frequency of occurrence varies: Pheretima alexandri was least frequently found (18 sites) and Lampito mauritii most frequently (70 sites), followed by Pontodrilus bermudensis (55 sites). Exotic species like Octochaetona surensis and Pontoscolex corethrurus and native peregrine species like Lampito mauritii that are widely distributed in southern parts of India (Odisha) area appear to be better adapted to withstand drought conditions, as they have enteronephricmeronephric excretory system, i.e., excrete their urine into the gut, for conservation of water in their bodies (Lee, 1985). The most common earthworm species in almost all the observed habitats across all the agro-climatic zones of Odisha were Lampito mauritii and Pontodrilus bermudensis. The presence of a species in a particular habitat and its absence from other habitats shows the species-specific distribution of earthworms in different pedoecosystems. A study conducted by Bossuyt, Six, and Hendrix (2006) showed that there was a significant influence of earthworm activity and residue application on stable aggregate formation. Further, in the presence of Eudrilus eugeniae, soil aggregates were three times greater than the control. During the survey only Lampito mauritii and Parionyx excavates anecic species and Pontoscolex corethrurus endogeic species found in North Eastern Ghat of Odisha, India. This showed that the soil layers of more than $30 \mathrm{~cm}$ deep were not suitable for propagation of earthworms. The earthworm fauna of southern Odisha, India are of all types belong to epigeic, endogeic, epi-anecic, endo-anecic, or anecic in nature. Edwards and Lofty (1977) suggest that earthworm species generally have narrow range in $\mathrm{pH}$, very few restricted to slightly acidic soils. Most of them prefer neutral soils, but some can tolerate acidic or alkaline soils. The $\mathrm{pH}$ values recorded in the present study are within the range for the distribution of earthworms. Eudrilus eugeniae and Octochaetona serrata inhabited cultivated soils while Eisenia

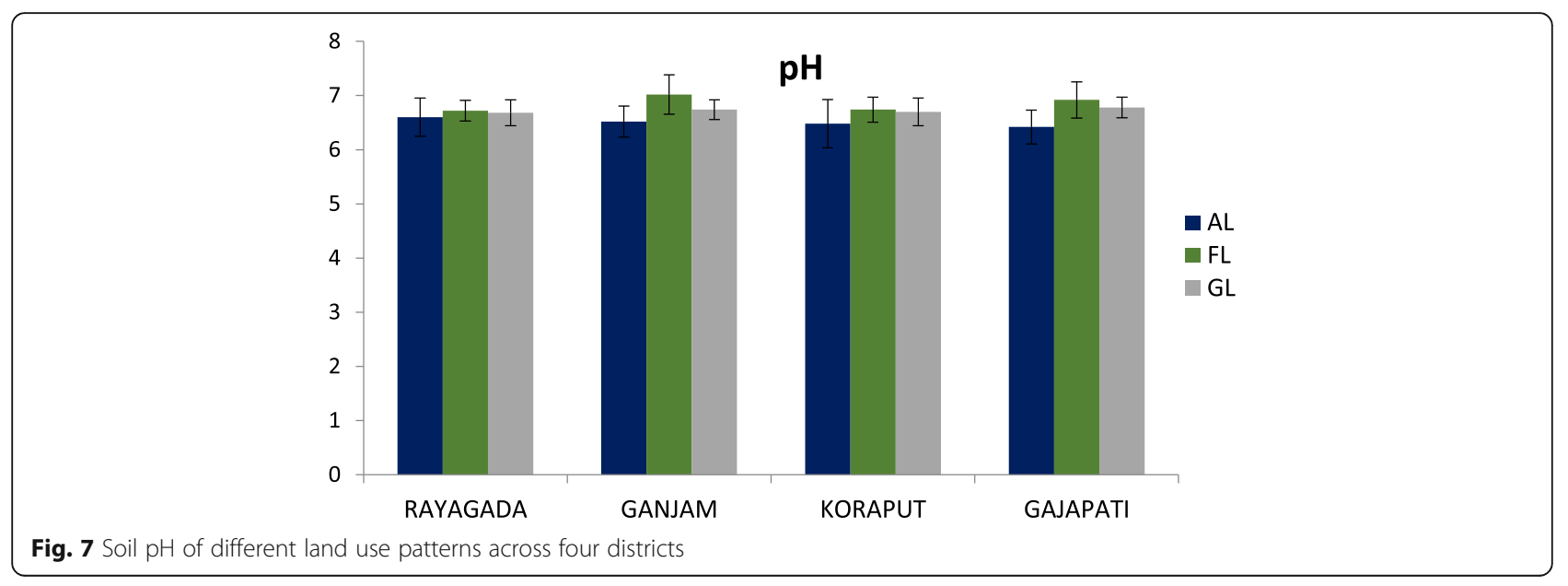


Table 5 Principal components and eigenvalues with total and cumulative variance of soil factors

\begin{tabular}{lllll}
\hline Soil parameters & PC1 & PC2 & PC3 & PC4 \\
\hline $\mathrm{C}$ & 1.000 & 1.000 & 1.000 & 1.000 \\
$\mathrm{~N}$ & .374 & .673 & .528 & .463 \\
$\mathrm{pH}$ & -.248 & -.398 & -.332 & -.367 \\
$\mathrm{P}$ & -.161 & .034 & .523 & .085 \\
$\mathrm{WHC}$ & .360 & .192 & .112 & .225 \\
$\mathrm{CEC}$ & .394 & -.176 & .311 & .264 \\
Eigen values & 2.212 & 2.130 & 2.133 & 2.241 \\
Total variance (\%) & 28.058 & 25.698 & 23.471 & 21.446 \\
Cumulative Variance & 35.504 & 42.354 & 61.254 & 74.342 \\
\hline
\end{tabular}

fetida and Perionyx gravely found in non-cultivated soil, reflecting a clear cut species-habitat relationship. The occurrence of Eudrilus eugeniae and Octochaetona serrata in cultivated soil might relate to higher $\mathrm{N}$ concentration. The earthworm species in grassland were Eisenia fetida, Pontoscolex corethrurus, and Perionyx gravely which were only present in grassland having high OC. The greater accumulation of litter on the surface soil of both agricultural and forest systems could provide sufficient space, food, shelter, and protection from predation of other animals to earthworm populations which also helps in enhancing the earthworm diversity (Ruan, Li, \& Zou, 2005) in the particular soil habitat conditions. Landscape structure and species-specific dispersal and colonization abilities may also have played a crucial role in population distribution among three habitats (Decaens \& Jimenez, 2002; Thomas, Folgarait, Lavelle, \& Rossi, 2004).

Principal component analysis (PCA) was used in order to study the interaction between physico-chemical soil parameters and earthworm communities of studied sites. PCA resulted in five principal components viz. PC1, PC2, PC3, and PC4 contributing variances of 28.058, 25.698, 23.471 , and 21.446 respectively (Table 5 ). This procedure makes it possible to group or distribute the sampling sites around principal axes in function of the physico-chemical

Table 6 Physico-chemical parameters of various land use patterns df: degrees of freedom ANOVA $(n=5)$

\begin{tabular}{llll}
\hline Physico-chemical properties of soil & Df & $f$ value & $p$ value \\
\hline Earthworm population & 2 & 29.83 & $<0.05$ \\
Organic carbon & 2 & 117.14 & $<0.05$ \\
Total nitrogen & 2 & 41.10 & $<0.05$ \\
pH & 2 & 7.12 & $<0.05$ \\
Phosphorus & 2 & 20.76 & $<0.05$ \\
Water holding capacity & 2 & 71.38 & $<0.05$ \\
Cation exchange capacity & 2 & 339.69 & $<0.05$ \\
\hline
\end{tabular}

and earthworm parameters, thus facilitating observation of possible links between variables and places where they are most represented (Figs. 8, 9, and 10).

\section{Agricultural land \\ Modern agricultural practices are leading to alter the} physical and chemical structure of soil environment subsequently modulating the changes in abundance and composition of earthworm population (Curry, Byrne, \& Schmidt, 2002) similar to this, Dale and Polasky (2007) mentioned that in agricultural systems, changes in land use patterns are the direct result of different practices of soil. Moreover, the use of pesticides and herbicides in intensive agricultural lands are going to affect earthworms in a way like from gene expression and physiology, to the individual as well as population distribution (Pelosi, Barot, Capowiez, Hedde, \& Vandenbulcke, 2014; Santadino, Coviella, \& Momo, 2014). Soil erosion in agricultural lands is one of the major threat to food security (Amundson et al., 2015). Agricultural practices leads to such a huge disturbance for many native earthworm species (James \& Hendrix, 2004) that even after agricultural abandonment native species may not be able to repopulate secondary forests at those regions. Tripathi and Bhardwaj (2004) reported high species richness in agricultural lands since in our study species richness was very low in cultivated lands, so the difference may be due to type of soil and agricultural practices at the concerned experimental sites. Changes in vegetation can also affect the distribution and earthworm population with change in litter quality and also through soil properties (Muys \& Granval, 1997).

In the present study, Eudrilus eugeniae, Octochaetona serrata, and Octochaetona surensis have been abundantly found in agriculture soil due to its endogeic ecological category which protects it directly from the effects of insecticides and pesticides and mechanical disturbance produced during agriculture practices. More plowing in agriculture field positively influence endogeic species by increasing organic matter availability and opposite effect from anecic species (Capowiez et al., 2009; Ernst \& Emmerling, 2009; Metzke, Potthoff, Quintern, Heß, \& Joergensen, 2007). Diversity of epigeic species like Lampito mauritii and Perionyx excavates in agricultural field was low may be due to physical disturbance of the soil during plowing and intensive use of insecticide and pesticide. The significant effect of experimental sites has been well examined on endogeic and anecic populations. Jouquet et al. (2010) also reported that endogeic earthworms are the most resistant earthworm recorded in disturbed soil. This burrowing nature of earthworm protects it from effects of insecticides and pesticides and also the mechanical pressure produced during agriculture management practices by the humans. However, 


\section{Scree Plot}

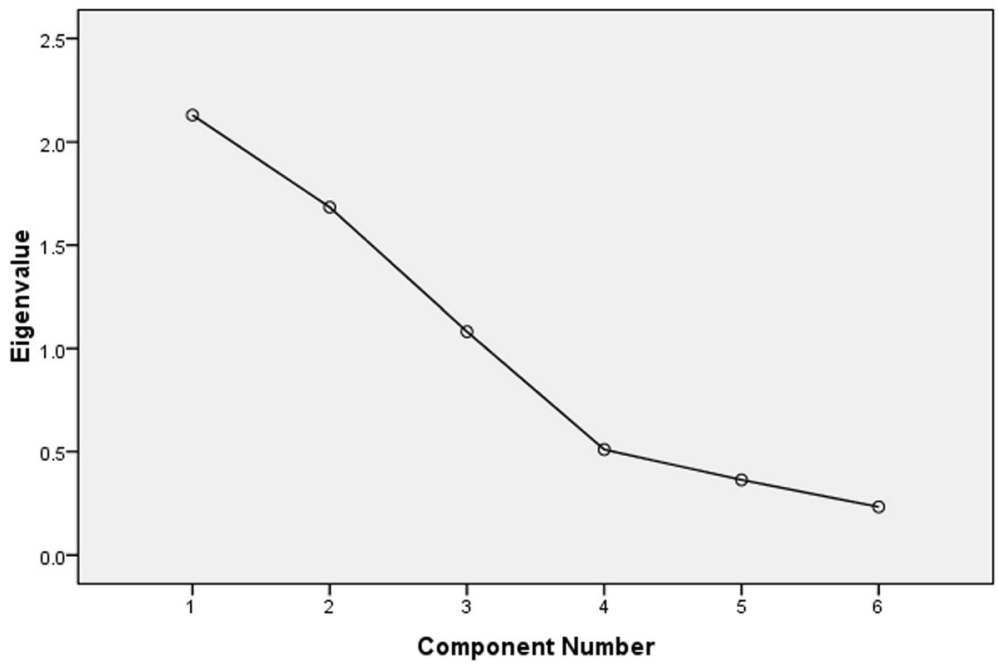

Fig. 8 Scree plot of eigenvalue of principal components for agriculture land

there is no significant effect of different irrigation and cropping practices on epigeic abundance. Cultivated soils usually have low organic matter compared with native ecosystem for earthworm, since agricultural activities increases aeration of soil which enhances the decomposition of soil organic concentration subsequently. The differences in agricultural management practices that affect the population density and biomass of earthworm were also observed by Amador, Winiarski, and Ramirez (2013). This difference in earthworm population density across various soil habitat conditions might attribute to change in vegetation patterns in some specific experimental sites. It is also observed that the earthworm abundance is directly influenced by the management practices of agricultural lands. Thus, understanding the influence of agricultural management on earthworms and their relationship with soil organic matter dynamics is imperative for the development of sustainable agroecosystems.

\section{Forest land}

Disturbance and degradation of natural forests leads to change in earthworm population structure and distribution reported by Baretta, Brown, James, Bran,

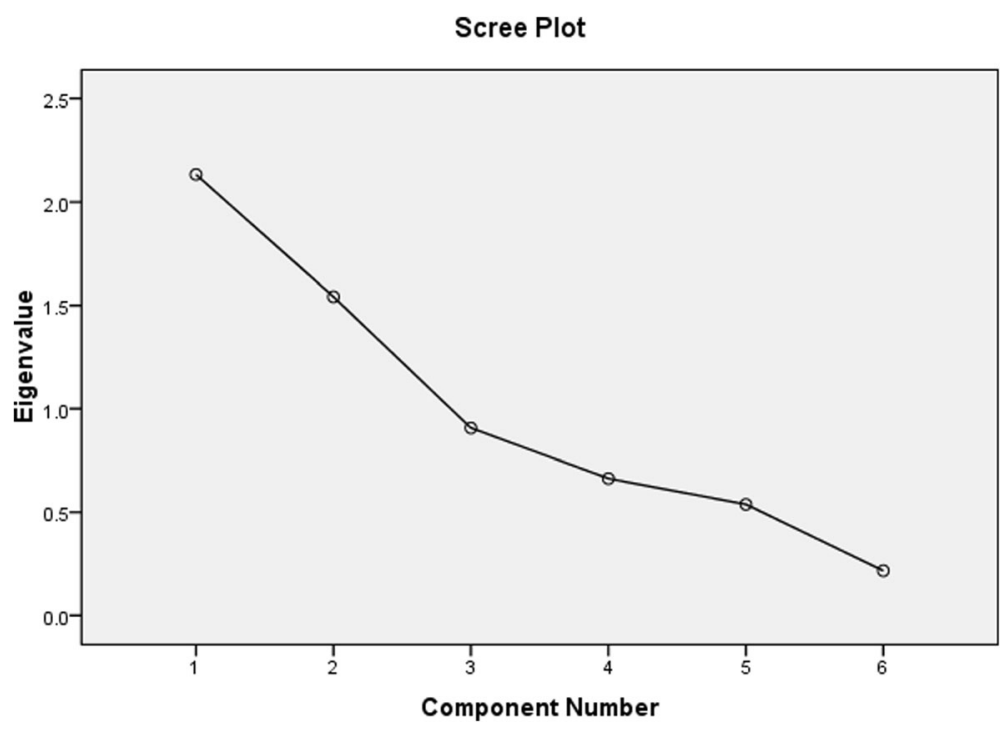

Fig. 9 Scree plot of eigenvalue of principal components for forest land 


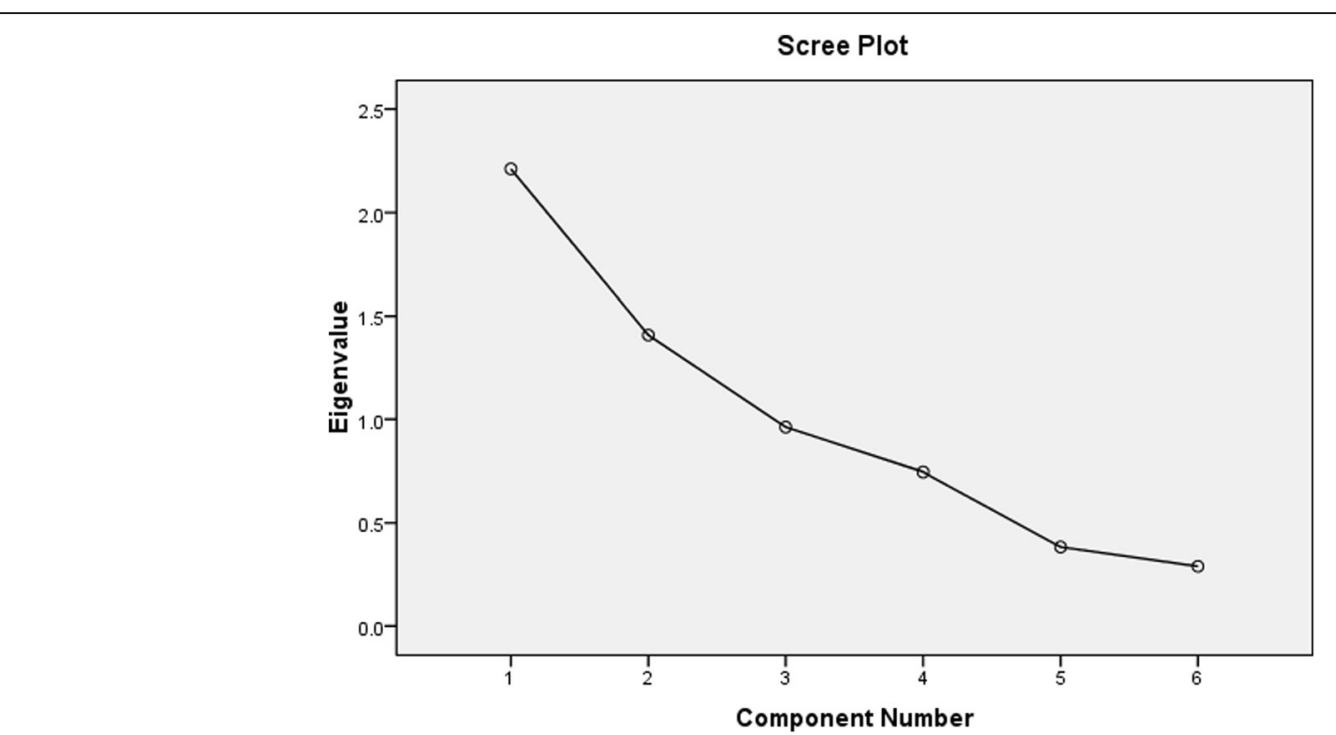

Fig. 10 Scree plot of eigenvalue of principal components for grass land

and Cardoso (2007) and Chandran, Sujatha, Mohan, Julka, and Ramasamy (2012) in both the tropical and temperate regions of the soil ecosystem around the world. Bohlen et al. (2004) studied that reductions in soil C:N ratios caused by earthworm invasion of previous uncolonized forest soils. The diversity and distribution of earthworm populations is also studied by Haokip and Singh (2012) from disturbed and undisturbed subtropical forest ecosystems of Imphal, Manipur, India. Joshi and Aga (2009) made a similar kind of investigation on diversity and distribution of earthworm populations in some of the subtropical forest ecosystems of Uttarakhand, India in which they reported temperature, water content of soil, oxidizable organic matter, $\mathrm{pH}$, phosphorous, potassium, calcium, and $\mathrm{N}$ as the potential factors influencing the diversity and distribution patterns of earthworm populations. In our study, species such as Pontodrilus bermudensis, Parionyx excavates, Pheretima alexandri, and Lampito mauritii were found abundantly in the forest areas of various habitats of districts viz. Rayagada, Ganjam, Koraput, and Gajapati (Table 1). Matson, Parton, Power, and Swift (1997) studied that the different species and their population density in the soil in tropical agricultural lands are less than $50 \%$ of that of the primary forest on that land. Agricultural conversion continues to threaten the tropical forests at some extent. Various studies reported that the disturbance and degradation of natural forest affect the number of earthworms and their distribution (Baretta et al., 2007; Chandran et al., 2012). Ayuke et al. (2009) reported that some earthworm groups which are found abundantly in the forest soils noticed positively correlated with $\mathrm{N}$.

\section{Grass land}

The distribution of different earthworm species is studied in various habitats of agro-climatic zones of Odisha, India. Eisenia fetida, Pontoscolex corethrurus, and Perio$n y x$ gravely were found in grassland ecosystem. Reasons for the dominance of natives in these pastures may be related to the land use history in the region, particularly its more recent colonization and the widespread use of native pastures in most of the regions. In few sites of grasslands, no earthworm was found at all. This is readily explained by the very sandy ( 90 to $98 \%$ sand) and nutrient-depleted soils in this site (Boeger, Wisniewski, \& Reissmann, 2005). These sandy soils, in the lower horizons at the high ground water level creates anoxic situations and the upper horizons dry out quickly because of drainage, both of which are fatal for earthworm population. The lack of available nutrients (organic matter) at this depth is because of relatively low input (litter fall) from the sparse plant cover, and very irregular distribution of litter in the younger stages (Pinto \& Marques, 2003) might negatively influence earthworm abundance (Lee, 1985).

Epigeic species observed $18 \%$ and $10 \%$ in permanent grasslands and agricultural land, respectively. The anecic species noticed $23 \%$ and $15 \%$ in permanent grasslands and agricultural land, respectively. The distribution of the different ecological categories of earthworms in arable land and permanent grasslands showed a preference of endogeic species, as soil dwellers with horizontal burrows. However, the numbers of endogeic species was found higher in grasslands than in agricultural land. Particularly in grasslands, the correlation between earthworm characteristics (earthworm density and distribution) and soil physico-chemical properties was not so much (Table 4). These are usually much abundant in grassland in comparison with in 
Table 7 Name of the species with sampling sites and habitat types

\begin{tabular}{|c|c|c|c|c|c|}
\hline Species & No of samples & Sampling site & Habitat & Species richness & Sampling date \\
\hline Pontodrilus bermudensis & 5 & Semiliguda, Koraput & Agricultural land & $11.61 \pm 2.31$ & 23.07 .2015 \\
\hline Pontodrilus bermudensis & 5 & Damonjodi, Koraput & Forest land & $20.36 \pm 2.22$ & 23.07.2015 \\
\hline Pontodrilus bermudensis & 5 & Jaypore, Koraput & Grass land & $14.8 \pm 1.54$ & 24.07 .2015 \\
\hline Lampito mauritii & 5 & Muninguda, Rayagada & Agricultural land & $20.4 \pm 2.45$ & 12.07.2015 \\
\hline Lampito mauritii & 5 & Ramanaguda, Rayagada & Forest land & $28.2 \pm 2.24$ & 13.07.2015 \\
\hline Lampito mauritii & 5 & Royat colony, Rayagada & Grass land & $23 \pm 1.54$ & 15.07.2015 \\
\hline Perionyx gravely & 5 & Kasipur, Rayagada & Agricultural land & $20.4 \pm 2.42$ & 16.07.2015 \\
\hline Perionyx gravely & 5 & Tikiri, Rayagada & Forest land & $22.2 \pm 2.11$ & 17.072015 \\
\hline Perionyx gravely & 5 & Kasturinagar, Rayagada & Grass land & $23 \pm 1.24$ & 15.07.2015 \\
\hline Eudrilus eugeniae & 5 & Bhanjanagar, Ganjam & Agricultural land & $22.3 \pm 1.36$ & 10.08 .2015 \\
\hline Eudrilus eugeniae & 5 & Mujagada forest, Ganjam & Forest land & $21.7 \pm 1.73$ & 11.08 .2015 \\
\hline Eudrilus eugeniae & 5 & Berhampur, Ganjam & Grass land & $18.2 \pm 2.41$ & 10.08 .2015 \\
\hline Octochaetona surensis & 5 & Chatrapur, Ganjam & Agricultural land & $20.8 \pm 1.43$ & 12.08 .2015 \\
\hline Octochaetona surensis & 5 & Buguda forest, Ganjam & Forest land & $18.2 \pm 2.12$ & 13.08.2015 \\
\hline Octochaetona surensis & 5 & Aska, Ganjam & Grass land & $14.3 \pm 1.22$ & 14.08.2015 \\
\hline Perionyx excavates & 5 & Bissamcucctack, Rayagada & Agricultural land & $15.2 \pm 2.62$ & 17.08.2015 \\
\hline Perionyx excavates & 5 & Gudari, Rayagada & Forest land & $22.2 \pm 2.24$ & 17.08.2015 \\
\hline Perionyx excavates & 5 & Gunupur colony, Rayagada & Grass land & $16.5 \pm 1.87$ & 18.08.2015 \\
\hline Pontoscolex corethrurus & 5 & Gajapatinagaram, Gajapati & Agricultural land & $13.7 \pm 1.23$ & 05.09 .2015 \\
\hline Pontoscolex corethrurus & 5 & Devagiri, Gajapati & Forest land & $15.3 \pm 2.53$ & 06.09 .2015 \\
\hline Pontoscolex corethrurus & 5 & Paralakhemundi, Gajapati & Grass land & $17.2 \pm 1.42$ & 05.09 .2015 \\
\hline Octochaetona serrate & 5 & Semiliguda, Koraput & Agricultural land & $22.35 \pm 2.22$ & 23.07.2015 \\
\hline Octochaetona serrate & 5 & Damonjodi, Koraput & Forest land & $20.2 \pm 2.21$ & 24.07.2015 \\
\hline Octochaetona serrate & 5 & Jaypore, Koraput & Grass land & $17.8 \pm 1.27$ & 23.07.2015 \\
\hline Pheretima alexandri & 5 & Mohana, Gajapati & Agricultural land & $12.33 \pm 1.23$ & 05.09.2015 \\
\hline Pheretima alexandri & 5 & Nuagada, Gajapati & Forest land & $18.34 \pm 2.53$ & 06.09 .2015 \\
\hline Pheretima alexandri & 5 & Kasinagar, Gajapati & Grass land & $15.95 \pm 1.93$ & 05.09.2015 \\
\hline Eisenia fetida & 5 & Rambha, Ganjam & Agricultural land & $18.6 \pm 2.61$ & 11.08.2015 \\
\hline Eisenia fetida & 5 & Polosara forest, Ganjam & Forest land & $20.3 \pm 1.82$ & 12.08 .2015 \\
\hline Eisenia fetida & 5 & Gopalpur, Ganjam & Grass land & $21 \pm 1.33$ & 10.08 .2015 \\
\hline
\end{tabular}

agricultural land, which is probably due to number of factors among which lesser availability of food and regular soil tillage in agricultural lands may be the most important causes (e.g., Barley, 1961; Boag, Palmer, Neilson, Legg, \& Chambers, 1997; Edwards \& Bohlen, 1996; Edwards \& Lofty, 1979; Evans \& Guild, 1948; Tischler, 1955; Zicsi, 1969) An exception to this is the position of the abundance of epigeic species, located close to that of Lumbricus rubellus, reflecting the dominance of this species in this ecological group. This may be regarded as an indication that the management type is important in determining the abundance in which earthworm populations occur. In particular, the higher amount of soil organic matter in grassland farms, and the less intensive soil cultivation may be decisive in this respect. The porosity of the upper layers decreased when the land used for pasturage particularly.

\section{Change in organic carbon and total nitrogen}

The significant correlations observed between earthworms and total $\mathrm{OC}$ and $\mathrm{N}$ amount contained within some of the fractions on a $\mathrm{gm}^{2}$ basis (e.g., micro-aggregates) may be because of the relationship between earthworms and the concentration of $\mathrm{C}$ and $\mathrm{N}$ in the whole soil, since the enrichment of the bulk soil would be associated with increases in $\mathrm{C}$ and $\mathrm{N}$ concentrations for at least some of the aggregate fractions comprising the whole soil. It is also observed the existence of positive correlation between OC and $\mathrm{N}, \mathrm{OC}$ and earthworm population and distribution. The similar kind of results, i.e., positive correlation observed between earthworm density and total soil C and N (Blanchart et al., 1999; Shipitalo \& Le Bayon, 2004). Some other studies (Kale, 1998; Sathianarayanan \& Khan, 2006) have also shown the high earthworm population density 
associated with high $\mathrm{C}$ and $\mathrm{N}$ ratio. It shows that earthworms prefer to live in soil ecosystems rich in organic matter and $\mathrm{N}$. The present observations are more or less in agreement to the findings of other workers (Appelhof, 1981; Edwards \& Lofty, 1977; Hallatt, Viljoen, \& Reinecke, 1992; Lavelle, 1974; Lee, 1985).

It is the relative values $\mathrm{OC}$ and $\mathrm{N}$ that affect the earthworm population. Soil $\mathrm{C}$ in forest soils in our study was significantly higher $(P<0.01)$ than grassland but the latter was significantly higher $(P<0.05)$ than agricultural land (Table 4). The species available at these sites are Eudrilus eugeniae and Perionyx excavates. Curry, Byrne, and Boyle (1995) noticed the contribution of earthworms by addition of 3.4-4.1 g of mineral nitrogen to the soil through excretion, mucus production, and soil ingestion in soil ecosystem. Selvakumar and Umamaheswari (2003) have also observed similar kind of results while analyzing the $\mathrm{N}$ concentration of the vegetable wastes composted by the earthworm species Eudrilus eugeniae. It also reported that the increased $\mathrm{N}$ concentration may be because of release of nitrogenous metabolic products through earthworm Eudrilus eugeniae excreta, urine, and mucoprotein components (Padmavathiamma, Li, \& Kumari, 2008). Indeed, Dash et al. (1977 \& 1979) studied the presence of higher levels of $\mathrm{N}$ in the casts of Lampito mauritii species than in the surrounding soil. Burtelow, Bohlen, and Groffman (1998) and Fonte, Thaiis, and Six (2009) observed the positive correlation between earthworm biomass with total soil OC and OC is positively correlated with distribution of earthworm. In our study, the $\mathrm{N}$ was positively correlated with the $\mathrm{OC}$ as well as $\mathrm{P}$ and WHC at some extent as overall. The bulk density of soil also differed in different sites. These correlations explain that soil fertility has a crucial role in the participation of earthworm that plays positive role across the soil ecosystem.

\section{Phosphorus concentration}

Coleman, Reid, and Cole (1983) observed the uptake of microorganisms like bacteria and fungi followed by grazing of microorganisms by the earthworms, excretion and decomposition resulted in release of $\mathrm{P}$ compounds which can be cycled through plants and again back to the soil. Similar kind of results were observed by Mansell, Syers, and Gregg (1981) with regard to the increase of short-term plant availability of $\mathrm{P}$ derived from plant litter by two- or threefold by the earthworms. The earthworm has some impacts on $\mathrm{P}$ dynamics and availability in the soil atmosphere depending on the physico-chemical properties of soil, as well as organic P source, and the burrowing behavior of earthworm (Bunemann, Oberson, \& Frossard 2011). In the present study, P was positively correlated with soil $\mathrm{OC}, \mathrm{N}$, and WHC and observed highest in forest land then grass land and agricultural land. The mineralization of phosphate also increased $\mathrm{P}$ concentration (Garg, Gupta, \& Satya, 2006; Kumar, Bhargava, Prasad, \& Pruthi, 2015). Study by Chaudhuri, Pal, Bhattacharjee, and Dey (2000) and Vinotha, Parthasarathi, and Ranganathan (2000) noticed that increase in available phosphorous concentration in worm-worked substrate is probably because of mineralization and mobilization of phosphorous by combined action of microbial activity in casts and also the fecal phosphatase of earthworms.

\section{Change in $\mathrm{pH}$}

The average $\mathrm{pH}$ value of soil in the study area was slightly acidic but very close to the neutral status that indicates a $\operatorname{good} \mathrm{pH}(6.42 \pm 0.31$ to $7.02 \pm 0.36)$ status and the existing $\mathrm{pH}$ value is positively correlated with the earthworms' distribution. A negative correlation of $\mathrm{pH}$ and $\mathrm{P}$ with earthworm number and biomass was observed by Iordache and Borza (2010). They also found that the phosphorous concentration of soil exerted has the greatest negative influence on earthworm biomass. The change in $\mathrm{pH}$ toward neutrality may due to the mineralization of $\mathrm{N}$ and $\mathrm{P}$ into nitrites or nitrates and orthophosphates (Kaviraj \& Sharma, 2003a, b). Chaudhuri and Bhattacharjee (1999) reported that earthworms are mostly distributed in a $\mathrm{pH}$ range of slightly acid to moderate alkaline, thus $\mathrm{pH}$ value recorded in the present study are within the range for the distribution of earthworms.

Earthworm population is available much in the soils with neutral $\mathrm{pH}$. The majority of species are in distribution range between $\mathrm{pH}$ of 6.0 and 7. 8. The $\mathrm{pH}$ may increase due to high solubility of nutrients in some earthworm casts (Barley, 1959). This could be another reason for the rise in $\mathrm{pH}$ of the substrates in our study. In the present study, decrease in $\mathrm{pH}$ (6.5) observed significantly $(P<0.05)$ in many sites of agricultural land. The decrease in $\mathrm{pH}$ could also be due to production of $\mathrm{CO}_{2}$, ammonia, $\mathrm{NO}_{3}{ }^{-}$, and organic acid during casting process as hypothesized by Yadav, Tare, and Ahammed (2010) and Song, Liu, Wu, Lin, Ye, Jiao, and $\mathrm{Hu},(2014)$.

The $\mathrm{pH}$ and $\mathrm{CEC}$ found negatively correlated across agriculture and grass land. Soil $\mathrm{pH}$ for agriculture soils was significantly lower than for forest soils but the latter was significantly lower than for grassland. Significant increase in soil pH after inoculation of different species of earthworms in culture medium corroborates the reports of Basker, Kirkman, and Macgregor (1994). Darwin (1883) and Lee (1985) noticed that the reason behind the change could be the fact that different species of earthworms, including Lumbricus terrestris, secrete calcium carbonate by their calciferous glands. The $\mathrm{pH}$ values measured in our study observed to be lower may be because of the fields used with urea ammonium nitrate fertilizer added frequently. At some experimental site in the forest habitat, a higher $\mathrm{pH}$ value in fresh 
earthworm cast compared with adjacent soil was observed. The higher $\mathrm{pH}$ of cast soil may be due to the ammonia secreted in the worm's gut. In this study, soil $\mathrm{pH}$ tends to increase in the agricultural lands. The $\mathrm{pH}$ values of natural forest, grassland, and agricultural lands varied significantly $7.02 \pm 0.36,6.78 \pm 0.19$, and $6.60 \pm$ 0.35 (Table 3), and natural forest and cultivated land were more acidic than those of pasture land. However at few experimental sites of agricultural land, soil $\mathrm{pH}$ was slightly increased with soil depth due to accumulation of basic cations. Lime concentration in forest and grassland soil was similar while lime concentration significantly increased under agricultural land. More or less a negative correlation was found between $\mathrm{pH}$ value of soil and earthworm species distribution in different habitats.

\section{Variation in WHC}

WHC in soils is primarily controlled by the pore-size distribution of soils and also the number of pores with specific surface area in a selected area. This suggests that increase in soil organic concentration with increased aggregation and decreased bulk density leads to increase the total pore space as well as the number of small pore sizes in a given area (Haynes, 2000; Khaleel, Reddy, \& Overcast, 1981). Generally, earthworm casts have a higher range of water holding capacity in comparison to bulk soils (Elliot, Knight, \& Anderson, 1990). In our study, forest soil of almost all district showed highest WHC ranges from 28.51 \pm 0.74 to $29.50 \pm 0.90$. The species present at higher WHC were Octochaetona surensis and Octochaetona serrate. These results are similar with the findings of Abbott and Parker (1981), who reported an increased infiltration of water due the activity of the geophagous earthworm species Microscolexdubuis in the presence of clover mulch. They also declared that decreased infiltration in grass plots were probably because of fine roots clogging soil pores.

Hence, our results suggest that the presence of grasses and legumes at the study areas affected the hydraulic conductivity through various mechanisms directly with root activity and indirectly through earthworm biomass alteration. Ehlers (1975) and Bouche (1977) reported that macropores formed by earthworms between 2 and $11 \mathrm{~mm}$ in diameter depends on the presence of ecological group of earthworms at the study sites, i.e., endogeic, epigeic, and anecic. Endogeic and epigeic earthworms that live in mineral soil above soil surfaces mainly form small and tortuous pores ranging between 2 and $5 \mathrm{~mm}$ in diameter in size (Pérès, Cluzeau, Curmi, \& Hallaire, 1998). Therefore, anecic species form pores size larger than $5 \mathrm{~mm}$ in diameter may reach as deep as $2 \mathrm{~m}$ into the soil (Edwards \& Bohlen, 1996) and subsequently enhance infiltration into deep soil layers (Shuster, Subler, \& McCoy, 2002). Different ecological group of earthworm has different impact on water flow also vary with burrowing behaviors through soil. (Edwards, Shipitalo, Owens, \& Norton, 1990).

\section{Effect of CEC}

CEC showed a positive and highly significant relationship with earthworm's abundance $(p<0.01)$. Also, CEC was highest $22.4 \pm 1.81 \mathrm{meq} / 100$ in the forest soils of Gajapati district, Odisha India which coincided with the highest earthworm abundance. The CEC is an electrochemical process by which earthworm obtains nutrients. Cation exchange requires very small particles with a large surface area to hold electrically charged ions. This reason may also account for the significant differences in the CEC of the casts compared with three different habitats at various sample collection sites. The exchangeable acidity (cations) was lowest in the agricultural lands of Rayagada and Ganjam districts but these differences were, however, not statistically significant. The species abundantly present in these regions were Lampito mauritii, Octochaetona surensis, and Pontodrilus bermudensis. However, both the positive and negative charges are present on colloid surfaces, and soils of this region dominated. Therefore, more cations (positive ions) attracted to exchange sites than anions (negative ions), and soils seems to have greater cation exchange capacities. Soil $\mathrm{pH}$ is one of the crucial soil properties found to be positively correlated with CEC (Foth, 1990). The CEC of soil organic matter and some clay minerals varies with $\mathrm{pH}$. CEC is lowest at soil $\mathrm{pH}$ of 3.5 to 4.0 and increase in the $\mathrm{pH}$ increased by liming an acid soil most probably. Soil organic concentration also influences $\mathrm{pH}$ value of surface soils, since it contributes a significant fraction of soil cation exchange capacity and causes the dissociation of weak acid functional groups on soil organic matter (Brady \& Weil, 1996).

\section{Conclusions}

Earthworm is one of the important components of soil ecosystem and has a key role in the development and maintenance of physico-chemical properties of soil by converting biodegradable materials and organic wastes into nutrient rich components. In the present study, ten species identified which belong to five different families are as follows: Lampito mauritii, Perionyx excavates, Pontodrilus bermudensis, Perionyx gravely, Eudrilus eugeniae, Octochaetona surensis, Pontoscolex corethrurus, Octochaetona serrata, Pheretima alexandri, and Eisenia fetida. Four species, i.e., Pontodrilus bermudensis, Parionyx excavates, Pheretima alexandri, and Lampito mauritii, are found most abundantly in forest lands, while the other six species are mostly found in agriculture and grass land. The populations of Eudrilus eugeniae, Octochaetona serrata, and Octochaetona surensis are found abundantly in several agricultural lands. Eisenia fetida, Pontoscolex corethrurus, and Perionyx gravely 
species are mostly found in the areas of grass lands. However, some of the populations are found at both the habitats of forest and grass land such as Lampito mauritii and Parionyx excavates. Principal component analysis also proved that several physico-chemical properties (OC, N, WHC) of soil has found positively influenced the abundance and distribution of earthworms across three land use patterns. In our study, it is noticed that the distribution of earthworm was higher in forest lands and followed by grasslands having high organic manure rather than agricultural land. Therefore, agricultural practices are needed to maintain such a way that confirming the availability of such earthworm population in field for long-term soil productivity.

\section{Acknowledgements}

We are highly thankful to the School of life sciences, Sambalpur University, Odisha for providing laboratory with equipment's and Zoological survey of India, Kolkata for helping in identifying the species.

\section{Funding}

This research work was funded by UGC New Delhi.

\section{Availability of data and materials}

Please contact author for data requests.

\section{Authors' contributions}

ASS was responsible for the experimental work and AP was responsible for preparation of manuscript. Both authors read and approved the final manuscript.

\section{Ethics approval and consent to participate}

Not applicable.

\section{Consent for publication}

Manuscript contains complete original data.

\section{Competing interests}

The authors declare that they have no competing interests.

\section{Publisher's Note}

Springer Nature remains neutral with regard to jurisdictional claims in published maps and institutional affiliations.

Received: 18 July 2018 Accepted: 7 November 2018

Published online: 27 November 2018

\section{References}

Abbott, l., \& Parker, C. A. (1981). Interactions between earthworms and their soil environment. Soil Biology and Biochemistry, 13, 191-197.

Amador, J. A., Winiarski, K., \& Ramirez, D. S. (2013). Earthworm communities along a forest-coffee agroecosystem gradient: preliminary evidence supporting the habitat-dependent feeding hypothesis. Tropical Ecology, 54, 365-374.

Amundson, R., Berhe, A. A., Hopmans, J. W., Olson, C., Sztein, A. E., \& Sparks, D. L. (2015). Soil and human security in the 21st century. Science, 348, 6235.

Appelhof, M. (1981). Current progress in earthworm research. Biocycle, 22, 36-38.

Ayuke, F. O., Karanja, N. K., Muya, E. M., Musombi, B. K., Mungatu, J., \& Nyamasyo, G. H. N. (2009). Macrofauna diversity and abundance across different land use systems in Embu, Kenya. Tropical and Subtropical Agroecosystems, 11, 371-384.

Baretta, D., Brown, G. G., James, S. W., Bran, E. J., \& Cardoso, N. (2007). Earthworm populations sampled using collection methods inAtlantic forests with Araucaria angustifolia. Scientia Agricola, 64(4), 384-392.

Barley, K. P. (1959). The influence of earthworms on soil fertility. II. Consumption of soil and organic matter by the earthworm Allolobophoracaliginosa (Savigny). Australian Journal of Agricultural Research, 10, 179-185.

Barley, K. P. (1961). The abundance of earthworms in agricultural land and their possible significance in agriculture. Advances in Agronomy, 13, 249-268.
Basker, A., Kirkman, J. H., \& Macgregor, A. N. (1994). Changes in potassium availability and other soil properties due to soil ingestion by earthworms. Biology and Fertility of Soils, 17(2), 154-158.

Behera, B. G., Dash, S., \& Senapati, N. C. (1999). Earthworm bio-indicators of forest land use pattern. Indian Forest, 124, 273-281.

Bennour, S. A., \& Nair, G. A. (1997). Density and biomass and vertical distribution of Aporrectodeacaliginosa (Savigny, 1826) (Oligochaeta, Lumbricidae) in Benghazi, Libya. Biology of Fertile Soil, 24, 102-105.

Bhadauria, T., \& Ramakrishnan, P. S. (1989). Earthworm population dynamics and contribution to nutrient cycling during cropping and fallow phases of shifting agriculture in north east India. Journal of Applied Ecology, 26, 505-520.

Bhadauria, T., Ramakrishnan, P. S., \& Srivastava, K. N. (2000). Diversity and distribution of endemeic and exotic earthworms in natural and regenerating ecosystems in the central Himalayas, India. Soil Biology \& Biochemistry, 32, 2045-2054.

Blanchart, E., Albrecht, A., Alegre, J., Duboisset, A., Gilot, C., Pashanasi, B., ..., Brussaard, L., (1999). Effects of earthworms on soil structure and physical properties. In P. Lavelle, L. Brussaard, \& P. Hendrix (Eds.), Earthworm Management in Tropical Agroecosystems, (pp. 149-171). Oxon: CAB International.

Blanchart, E., \& Julka, J. M. (1997). Influence of forest disturbance on earthworm (Oligochaeta) communities in the Western Ghats (South India). Soil Biology \& Biochemistry, 29, 303-306.

Blouin, M., Hodson, M. E., Delgado, E. A., Baker, G., Brussaard, L., Butt, K. R., ... Brun, J. J. (2013). A review of earthworm impact on soil function and ecosystem services. European Journal of Soil Science, 64, 161-182.

Boag, B., Palmer, L. F., Neilson, R., Legg, R., \& Chambers, S. J. (1997). Distribution, prevalence and intensity of earthworm populationsin arable land and grassland in Scotland. Annals of Applied Biology, 130, 153-165.

Boeger, M. R. T., Wisniewski, C., \& Reissmann, C. B. (2005). Nutrientesfoliares de espéciesarbóreas de trêsestádiossucessionais de florestaombrófi la densa no Sul do Brasil. Acta Botanica Brasilica, 19, 167-181.

Bohlen, P. J., Parmelee, R. W., McCartney, D. A., \& Edwards, C. A. (1997), Earthworm effects on $\mathrm{OC}$ and nitrogen dynamics of surface litter in corn agroecosystems. Ecological Applications, 7, 1341-1349.

Bohlen, P. J., Scheu, S., Hale, C. M., McLean, M. A., Migge, S., Groffman, P. M., \& Parkinson, D. (2004). Non-native invasive earthworms as agents of change in northern temperate forests. Frontiers in Ecology and the Environment, 2, 427-435.

Bossuyt, H., Six, J., \& Hendrix, P. F. (2006). Interactive effects of functionally different earthworm species on aggregation and incorporation and decomposition of newly added residue OC. Geoderma, 130(1-2), 14-25.

Bouche, M. B. (1977). Strategies lombriciennes. Ecological Bulletins, 25, 122-132.

Brady, N. C., \& Weil, R. R. (1996). The nature and properties of soils, Prentice Hall Inc, Upper Saddle River. (pp. 343-490).

Bremner, J. M. (1996). Nitrogen-total. In Methods of soil analysis. Part 3. Chemical methods, (pp. 1085-1121). USA: Soil Sci. Soc. Am. Am. Soc. Agron.

Bunemann, E. K., Oberson, A., \& Frossard, E. (Eds.) (2011). Phosphorus in action, (p. 483). Berlin Heidelberg: Springer-Verlag.

Burtelow, A. E., Bohlen, P. J., \& Groffman, P. M. (1998). Influence of exotic earthworm invasion on soil organic matter, microbial biomass and denitrification potential in forest soils of the northeastern United States. Applied Soil Ecology, 9, 197-202.

Butenschoen, O., Ji, R., Schaeffer, A., \& Scheu, S. (2009). The fate of catechol in soil as affected by earthworms and clay. Soil Biology and Biochemistry, 41, 330339. https://doi.org/10.1016/.soilbio.2008.11.010.

Capowiez, Y., Cadoux, S., Bouchant, P., Ruy, S., Roger-Estrade, J., Richard, G., \& Boizard, H. (2009). The effect of tillage type and cropping system on earthworm communities, macroporosity and water infiltration. Soil and Tillage Research, 105, 209-216.

Chandran, M. S. S., Sujatha, S., Mohan, M., Julka, J. M., \& Ramasamy, E. V. (2012). Earthworm diversity at Nilgiri biosphere reserve, Western Ghats, India. Biodiversity and Conservation, 21, 3343-3353.

Chapman, H. D. (1965). Cation-exchange capacily. In C. A. Black (Ed.), Methods of soil analysis, part 2 agronomy, (vol. 9, pp. 891-901). Madrion: Am. Soc. Agron.

Chaudhuri, P. S., \& Bhattacharjee, G. (1999). Earthworm resources of Tripura. Proceedings of National Academy of Sciences, India, 69, 159-170.

Chaudhuri, P. S., Pal, T. K., Bhattacharjee, G., \& Dey, S. K. (2000). Chemical changes during vermicomposting (Perionyxexcavatus) of kitchen waste. Tropical Ecology, 41, 107-110.

Coleman, D. C., Reid, C. P., \& Cole, C. V. (1983). Biological strategies of nutrient cycling in soil systems. Advances in Ecological Research, 13, 1-55.

Curry, J. P., Byrne, D., \& Boyle, K. E. (1995). The earthworm population of winter cereal field and its effect on soil and nitrogen turn over. Biology and Fertility of Soil, 19, 166-172. 
Curry, J. P., Byrne, D., \& Schmidt, O. (2002). Intensive cultivation can drastically reduce earthworm populations in arable land. European Journal of Soil Biology, 38, 127-130. https://doi.org/10.1016/S1164-5563(02)01132-9.

Dale, V. H., \& Polasky, S. (2007). Measures of the effects of agricultural practices on ecosystem services. Ecological Economics, 64, 286-296. https://doi.org/10. 1016/j.ecolecon.2007.05.009.

Darwin, C. (1883). The chemical formation of vegetable Mould through the actions of worms, with observations on their habits. New York: D. Appleton \& Co.

Dash, M. C., \& Patra, U. C. (1977). Density, biomass and energy budget of a tropical earthworm population from a grassland site in Orissa, India. Revue d'Écologie et de Biologie du Sol, 14(3), 461-471.

Dash, M. C., \& Patra, U. C. (1979). Wormcast production and nitrogen contribution to soil by a tropical earthworm population from a grassland site in Orissa, India. Revue d'Écologie et de Biologie du Sol, 16(1), 79-83.

Decaens, T., \& Jimenez, J. J. (2002). Earthworm communities under an agricultural intensification gradient in Colombia. Plant and Soil, 240, 133-143.

Edwards, C. A., \& Bohlen, P. J. (1996). Earthworm ecology and biology, (pp. 196212). London: Chapman \& Hall.

Edwards, C. A., \& Lofty, J. R. (1977). Biology of earthworms, (p. 333). New York: Chapman and Hall.

Edwards, C. A., \& Lofty, J. R. (1979). Nitrogenous fertilizers and earthworms populations in agricultural soils. Soil Biology and Biochemistry, 147, 515-521.

Edwards, W. M., Shipitalo, M. J., Owens, L. B., \& Norton, L. D. (1990). Effect of Lumbricus terrestris $L$. burrows on hydrology of continuous no-till corn fields. Geoderma, 46, 73-84.

Ehlers, W. (1975). Observations on earthworm channels and infiltration on tilled and untilled loess soil. Soil Science, 119, 242-249.

Elliot, P. W., Knight, E., \& Anderson, J. M. (1990). Denitrification in earthworm casts and soil from pastures under different fertilizer and drainage regimes. Soil Biology and Biochemistry, 22, 601-605.

Ernst, G., \& Emmerling, C. (2009). Impact of five different tillage systems on soil organic OC content and the density, biomass, and community composition of earthworms after a ten year period. European Journal of Soil Biology, 45, 247-251.

Evans, A. C., \& Guild, W. J. M. L. (1948). Studies on the relationships between earthworms and soil fertility. V. Field populations. Annals of Applied Biology, 35, 485-493.

Evans, A. C., \& Guild, W. J. M. L. (1947). Studies on the relationship between earthworm and soil fertility I biological studies in the field. The Annals of Applied Biology, 34(3), 307-330.

Fonte, S. J., Thaiis, W., \& Six, J. (2009). Earthworm populations in relation to soil organic matter dynamics and management in California tomato cropping systems. European Journal of Soil Biology, 4, 206-214.

Foth, H. D. (1990). Fundamentals of soil Sciens. Canada: Wiley.

Garg, P., Gupta, A., \& Satya, S. (2006). Vermicomposting of different types of waste using Eisenia foetida: a comparative study. Bioresource Technology, 97, 391-395.

Ghosh, A. B., Bajaj, J. C., Hasan, R., \& Singh, D. (1983). Soil and water testing methods. A laboratory manual, division of soil science and agricultural chemistry, (pp. 1-48). New Delhi: IARI.

Guild, W. J. M. L. (1952). Variation in earthworm number within field population. The Journal of Animal Ecology, 21, 169-181.

Hackenberger, D. K., \& Hackenberger, B. K. (2014). Earthworm community structure in grassland habitats differentiated by climate type during two consecutive seasons. European Journal of Soil Biology, 61, 27-34.

Hallatt, L., Viljoen, S. A., \& Reinecke, A. J. (1992). Moisture requirements in the life cycle of Perionyx excavatus (Oligochaeta). Soil Biology and Biochemistry, 24, 1333-1340.

Haokip, S. L., \& Singh, T. B. (2012). Diversity and distribution of earthworms in a natural reserved and disturbed sub-tropical forest ecosystem of Imphal-West, Manipur, India. International Multidisciplinary Research Journal, 2(2), 28-34.

Haynes, R. J. (2000). Interactions between soil organic matter status, cropping history, method of quantification and sample pretreatment and their effects on measured aggregate stability. Biology and Fertility of Soils, 30, 270-275.

Holland, J. M. (2004). The environmental consequences of adopting conservation tillage in Europe: reviewing the evidences. Agriculture, Ecosystems \& Environment, 103, 1-25.

Iordache, M., \& Borza, I. (2010). Relation between chemical indices of soil and earthworm abundance under chemical fertilization in Romania. Plant, Soil and Environment, 56, 401-407.

James, S. W. (1991). Soil, nitrogen, phosphorus, and organic matter processing by earthworms in tallgrass prairie. Ecology, 72, 2101-2109.

James, S. W., \& Hendrix, P. F. (2004). Invasion of exotic earthworms into North America and other regions. In C. A. Edwards (Ed.), Earthworm ecology, (pp. 75-84). Boca Raton: CRC Press.
Joshi, N., \& Aga, S. (2009). Diversity and distribution of earthworms in a subtropical forest ecosystem in Uttarakhand, India. The Natural History Journal of Chulalongkorn University, 9(1), 21-25.

Jouquet, P., Plumere, T., Thu, T. D., Rumpel, C., Duc, T. T., \& Orange, D. (2010). The rehabilitation of tropical soils using compost and vermicompost is affected by the presence of endogeic earthworms. Applied Soil Ecology, 46, 125-133.

Julka, J. M., \& Paliwal, R. (2005). Distribution of earthworms in different agroclimatic region of India. In P. S. Ramakrishnan, K. G. Saxena, K. G. Swift, \& R. K. RauksMaikhuri (Eds.), Soil biodiversity, ecological processes and landscape, (pp. 3-13). Oxford and New Delhi: ABH Publication Co. and Pvt. Ltd..

Julka, J. M., \& Senapati, B. K. (1987). Records of the Zoological Survey of India, Miscellaneous Publication. Occ.pap.92, (pp. 1-105). Calcutta: Grafic Printall.

Kale, R. D. (1998). Earthworm: Cinderella of organic farming. Bangalore: Prism Books Pvt. Ltd.

Kale, R. D., \& Karmegam, N. (2010). The role of earthworms in tropics with emphasis on Indian ecosystems (Review Article). Applied and Environmental Soil Science, Article I D414356, 16.

Kaviraj, M., \& Sharma, S. (2003b). Municipal solid wastes management through vermicomposting employing exotic and local species of earthworm. Bioresource Technology, 90, 169-173.

Kaviraj, \& Sharma, S. (2003a). Municipal solid waste management through vermicomposting employing exotic and local species of earthworms. Bioresource Technology, 90, 169-173.

Khaleel, R., Reddy, K. R., \& Overcast, M. R. (1981). Changes in soil physical properties due to organic waste applications: a review. Journal of Environmental Quality, 10, 133-141.

Kumar, T., Bhargava, R., Prasad, K. S. H., \& Pruthi, V. (2015). Evaluation of vermifiltrations process using natural ingredients for effective wastewater treatment. Ecological Engineering, 75, 370-377.

Lalthanzara, H., Ramanujam, S. N., \& Jha, L. K. (2011). Population dynamics of earthworm in relation to soil physico-chemical parameters in agroforestry systems if Mizoram, India. Journal of Environmental Biology, 32, 599-605.

Lattaud, C., Locati, S., Mora, P., \& Rouland, C. (1998). The diversity of digestive systems in tropical geophagous earthworms. Applied Soil Ecology, 9, 189-195.

Lavelle, P. (1974). Les vers de terre de la savane de Lamto. Bulletin de Liaison des Chercheurs de Lamto, 5, 133-166.

Lavelle, P. (1997). Faunal activities and soil processes: adaptive strategies that determine ecosystem function. Advances in Ecological Research, 27, 93-132.

Lavelle, P., \& Spain, A. (2001). Soil ecology. Dordrecht: Kluwer Academic Publishers.

Lavelle, P. (1988). Earthworm activities and the soil system. Biology and Fertility of Soils., 6, 237-251. https://doi.org/10.1007/BF00260820.

Lee, K. E. (1985). Earthworms: their ecology and relationships with soils and land use, (pp. 224-411). New York: Academic Press.

Lee, K. E., \& Foster, R. C. (1991). Soil fauna and soil structure. Australian Journal of Soil Research, 29(6), 745-775.

Leroy, B. L. M., Schmidt, O., Van den Bossche, A., Reheul, D., \& Moens, M. (2008), Earthworm population dynamics as influenced by the quality of exogenous organic matter. Pedobiologia, 52(2), 139-150.

Leroy, B. L. M., Van den Bossche, A., De Neve, S., Reheul, D., \& Moens, M. (2007). The quality of exogenous organic matter: short-term influence on earthworm abundance. European Journal of Soil Biology, 43, 196-200.

Mansell, G. P., Syers, J. K., \& Gregg, P. E. H. (1981). Ibrd 13: 163-167 Murphy, J.; Riley, J.P. 1962 Am/. Chimica Acta, 27, 31-36.

Matson, P. A., Parton, W. J., Power, A. G., \& Swift, M. J. (1997). Agricultural intensification and ecosystem properties. Science, 277, 504-509.

Metzke, M., Potthoff, M., Quintern, M., Heß, J., \& Joergensen, R. G. (2007). Effect of reduced tillage systems on earthworm communities in a 6-year organic rotation. European Journal of Soil Biology, 43, S209-S215.

Muys, B., \& Granval, P. (1997). Earthworms as bio-indicators of forest site quality. Journal of Soil Biology and Biochemistry, 29, 323-328.

Nelson, D. W., \& Sommers, L. E. (1996). Total carbon, organic carbon, and organic matter. In Methods of soil analysis. Part 3. Chemical methods, Soil Science Society of America and American Society of Agronomy, U.S.A., (pp. 961-1010).

Nunes, D. H., Pasini, A., Benito, N. P., \& Brown, G. G. (2006). Earthworm diversity in four land use systems in the region of Jaguapita, Parana state, Brazil. Caribbean Journal of Science, 42, 331-338.

Padmavathiamma, P. K., Li, L. Y., \& Kumari, U. R. (2008). An experimental study of vermi-biowaste composting for agricultural soil improvement. Bioresource Technology, 99(6), 1672-1681.

Pelosi, C., Barot, S., Capowiez, Y., Hedde, M., \& Vandenbulcke, F. (2014). Pesticides and earthworms. A review. Agronomy for Sustainable Development, 34, 199228. https://doi.org/10.1007/s13593-013-0151-z. 
Pérès, G., Cluzeau, D., Curmi, P., \& Hallaire, V. (1998). Earthworm activity and soil structure changes 1431 due to organic enrichments in vineyard systems. Biology \& Fertility of Soils, 27, 417-424.

Pinto, C. B., \& Marques, R. (2003). Aporte de nutrientesporfrações da serapilheiraemsucessãoecológica de um ecossistema da Floresta Atlântica. Revista Floresta, 33, 257-264.

Rajkhowa, D. J., Bhattacharyya, P. N., Sarma, A. K., \& Mahanta, K. (2014). Diversity and distribution of earthworms in different soil habitats of Assam, north-east India, an Indo-Burma biodiversity hotspots. Proceedings of the National Academy of Sciences, India Section B: Biological Sciences, 85(2), 389-396.

Rajkhowa, D. J., Bhattacharyya, P. N., Sarma, A. K., \& Mahanta, K. (2015). Diversity and distribution of earthworms in different soil habitats of Assam, north-east India, an Indo-Burma biodiversity hotspot. Proceedings of the National Academy of sciences, India Section B: Biological Sciences, 85(2), 389-396.

Ramanujam, S. N., Roy, B., \& Jha, L. K. (2000). Inventory studies on the earthworm population in agroforestry systems of Mizoram. In Proc. Intl. Workshop on agroforestry and forest products, Aizawl, (pp. 191-194).

Reinecke, A. J., Albertus, R. M. C., Reinecke, S. A., \& Larink, O. (2008). The effects of organic and conventional management practices on feeding activity of soil organisms in vineyards. African Zoology, 43(1), 66-74.

Ruan, H., Li, Y., \& Zou, X. (2005). Soil communities and plant litter decomposition as influenced by forest debris: variation acrosstropical riparian and upland sites. Pedobiologia, 49, 529-538.

Santadino, M. V., Coviella, C. E., \& Momo, F. R. (2014). Glyphosate sublethal effects on the population dynamics of the earthworm Eisenia fetida (Savigny, 1826). Water, Air, and Soil Pollution, 225, 2207. https://doi.org/10.1007/s11270-014-2207-3.

Satchell, J. E. (1955). Some aspects of earthworm ecology. In D. K. Kevan, \& M. E. Butterworths (Eds.), Soil Zoology, Academic Press, New York. (pp. 180-201). London.

Sathianarayanan, A., \& Khan, A. B. (2006). Diversity, distribution and abundance of earthworms in Pondicherry region. Tropical Ecology, 47, 139-144.

Selvakumar, S., \& Umamaheswari, S. (2003). Physico-chemical and microbial characteristics of vermicompost produced by Eudriluseugeniae, Kinberg with note on their fecundity in vegetable waste. M.Sc. Thesis, Periyar University, (p. 60).

Sharma, J. C., \& Yogender, S. (2004). Effect of forest ecosystems on soil properties - a review. Agricultural Reviews, 25(1), 16-28.

Shipitalo, M. J., \& Le Bayon, R. C. (2004). Quantifying the effects of earthworms on soil aggregation and porosity. In C. A. Edwards (Ed.), Earthworm ecology, (pp. 183-200). Boca Raton: CRC Press.

Shuster, W. D., Subler, S., \& McCoy, E. L. (2002). The influence of earthworm community structure on the distribution and movement of solutes in a chiseltilled soil. Applied Soil Ecology, 21, 159-167.

Singh, J. (1997). Habitat preferences of selected Indian earthworms species and their efficiency in reduction of organic materials. Soil Biology and Biochemistry, 29, 585-588.

Singh, S., Singh, J., \& Vig, A. P. (2016). Effect of abiotic factors on the distribution of earthworms in different land use patterns. The Journal of Basic \& Applied Zoology, 74, 41-50

Song, X., Liu, M., Wu, D., Lin, Q., Ye, C., Jiao, J., \& Hu, F. (2014). Heavy metal and nutrient changes during vermicomposting animal manure spiked with mushroomresidues. Waste Management, 34, 1977-1983.

Svendsen, J. A. (1957). The distribution of Lumbricidae in an area of Penine moorland (Moor House, Nature Reserve). The Journal of Animal Ecology, 26(2), 411-421.

Tao, Y., Gu, W., Chen, J., Tao, J., Xu, Y. J., \& Zhang, H. (2013). The influence of land use practices on earthworm communities insaline agriculture soils of the west coast region of China's Bohai Bay. Plant, Soil and Environment, 59(1), 8-13.

Thomas, F., Folgarait, P., Lavelle, P., \& Rossi, J. P. (2004). Soil macrofaunal communities along an abandoned rice field chronosequence in Northern Argentina. Applied Soil Ecology, 27, 23-29.

Tischler, W. (1955). Effect of agricultural practice on the soil fauna. In D. K. M. Kevan (Ed.), Soil zoology, (pp. 215-230). London: Butterworths.

Tripathi, G., \& Bhardwaj, P. (2004). Comparative studies on biomass production, life cycles and composting efficiency of Eiseniafetida (Savigny) and Lampito mauritii(Kinberg). Bioresource Technology, 92, 275-278.

Vinotha, S. P., Parthasarathi, K., \& Ranganathan, L. S. (2000). Enhanced phosphatase activity in earthworm casts is more of microbial origin November. Current Science, 79(9), 1158-1159.

Yadav, K. D., Tare, V., \& Ahammed, M. M. (2010). Vermicomposting of source separated human faeces for nutrient recycling. Waste Management, 30, 50-56.

Zicsi, A. (1969). Über die Auswirkung der Nachfrucht und Bodenbearbeitung auf die Aktivität der Regenwürmer. Pedobiologia, 9, 141-146.

\section{Submit your manuscript to a SpringerOpen ${ }^{\odot}$ journal and benefit from:}

- Convenient online submission

- Rigorous peer review

- Open access: articles freely available online

High visibility within the field

- Retaining the copyright to your article

Submit your next manuscript at $>$ springeropen.com 